مجلة الاقتصاد المنزلى - مجلد 26 العدد الأول - 2016

\section{Journal of Home \\ Economics}

http://homeEcon.menofia.edu.eg

$$
\text { مجلد 26- العدد الأول- مجلة 2016م }
$$

ISSN 1110-2578

\title{
مشاركة الشباب الجامعي ببرامج إدارة رعاية الشباب وعلاقتها بمهارات إدارة الأت والقدرة على التخطيط للمستقبل
}

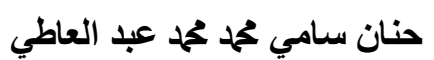

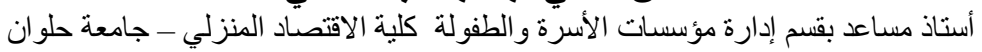

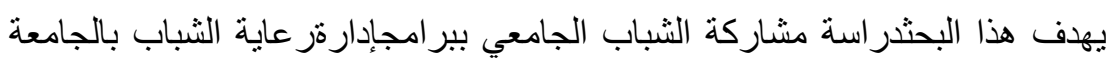

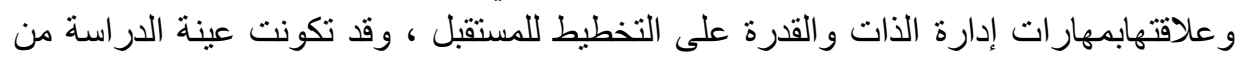

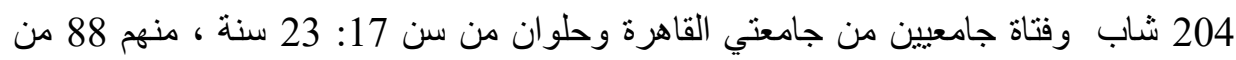

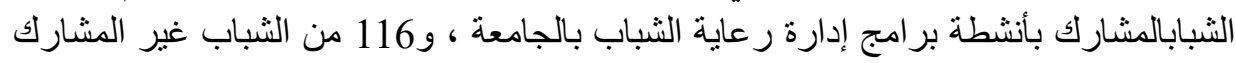

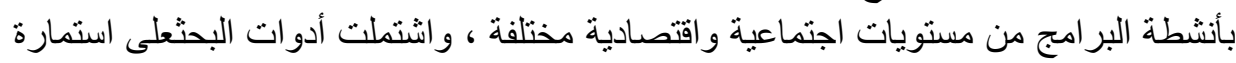

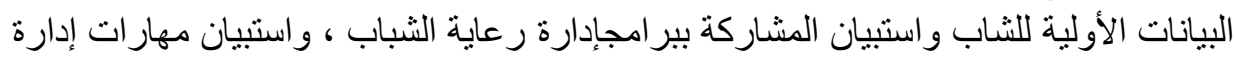

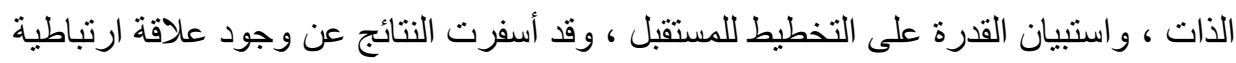

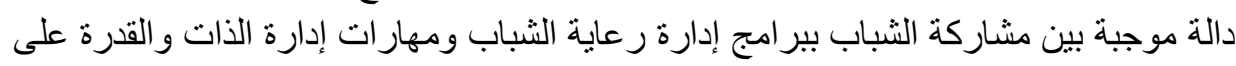

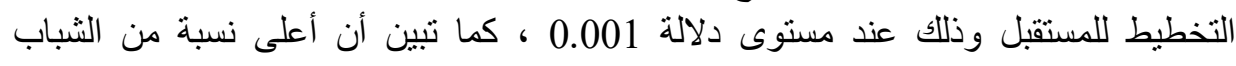

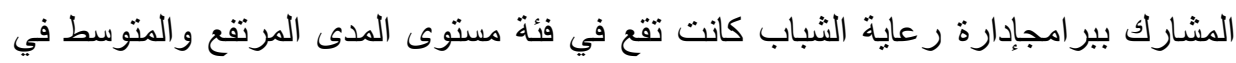

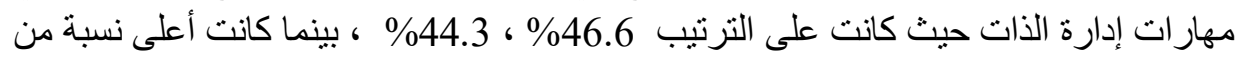

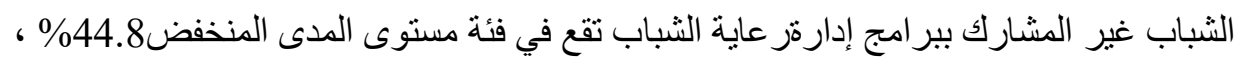

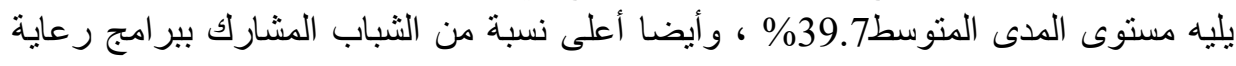

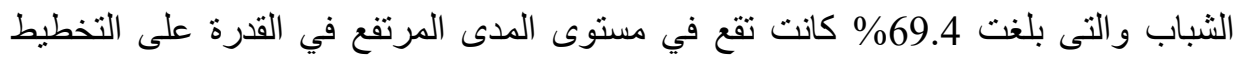

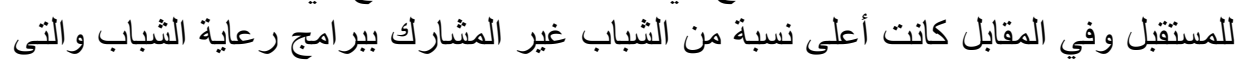

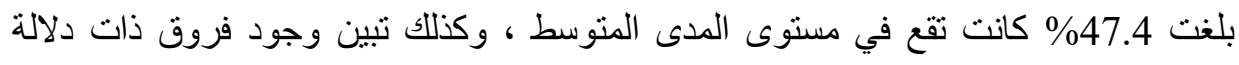

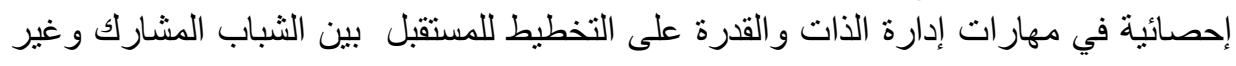

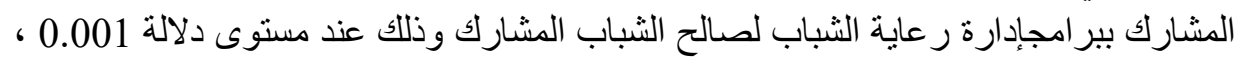

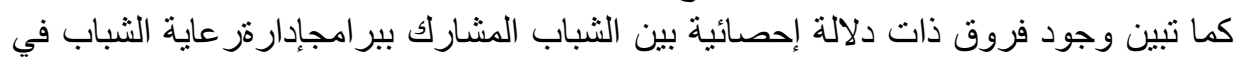

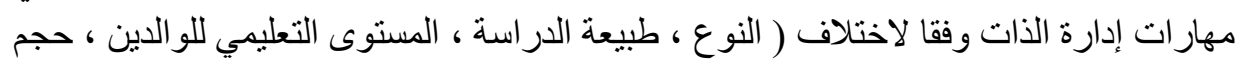

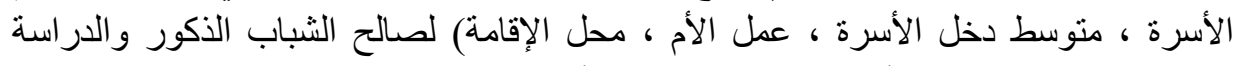

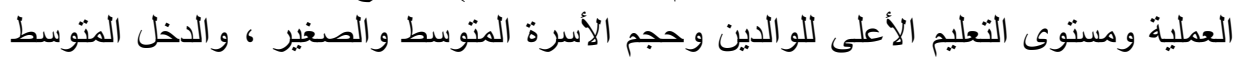

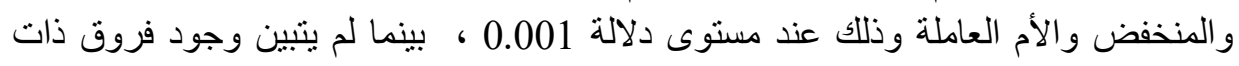




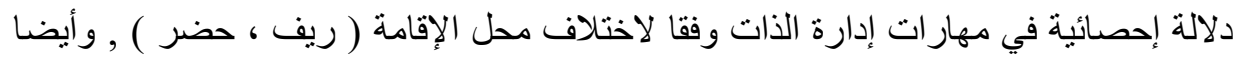

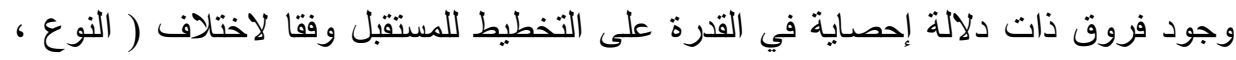

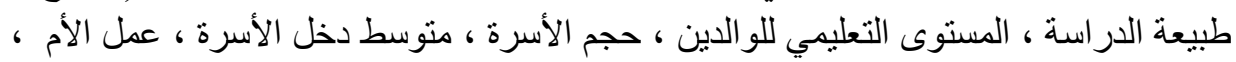

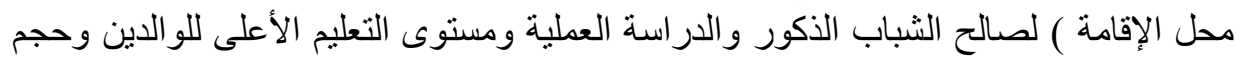

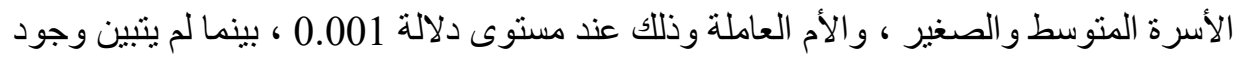

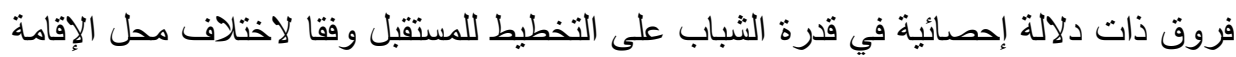
ومتوسط الدخل .

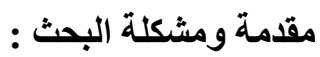
يمثل الثباب المحور الأساسى والركيزة الرئيسية التى تعتمد عليها المجتمعات

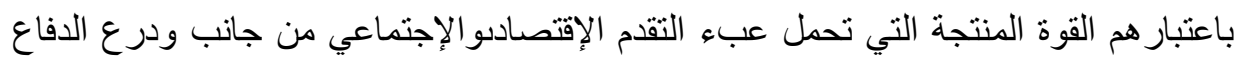

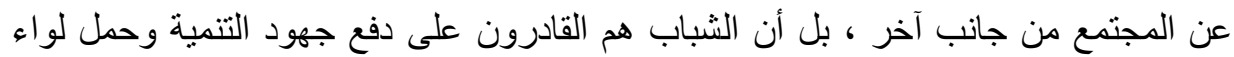

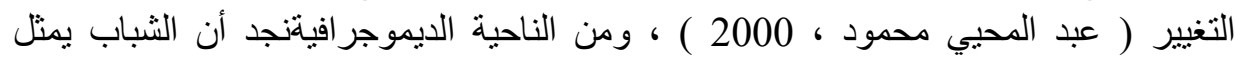

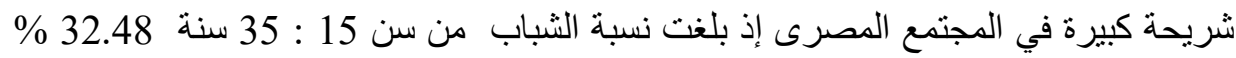

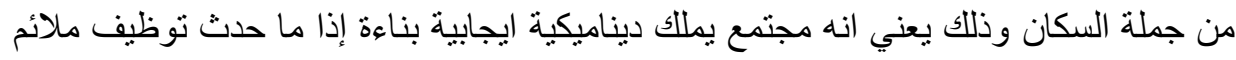

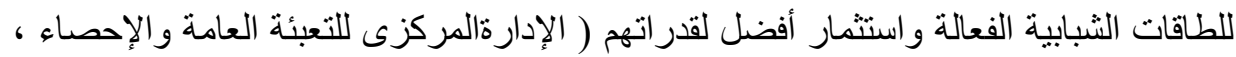

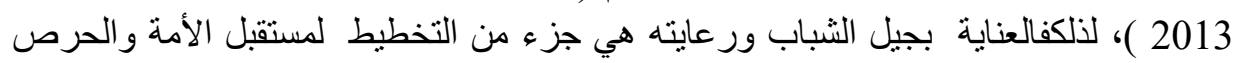

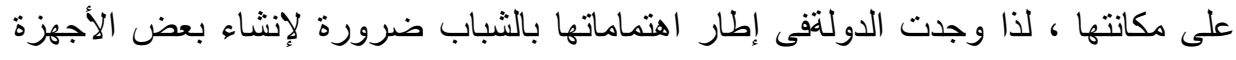

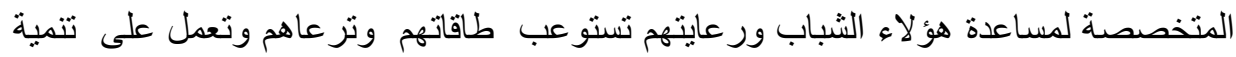

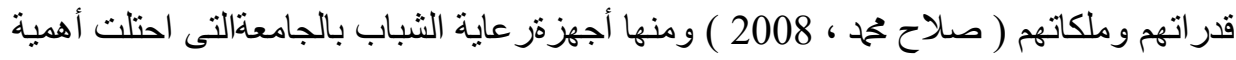

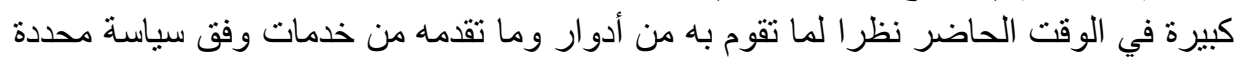

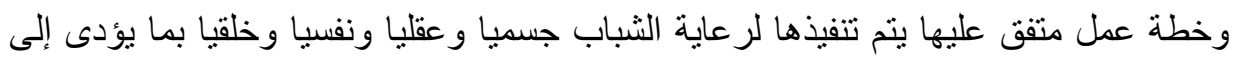

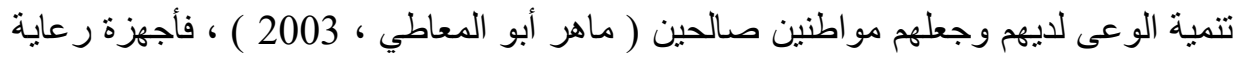

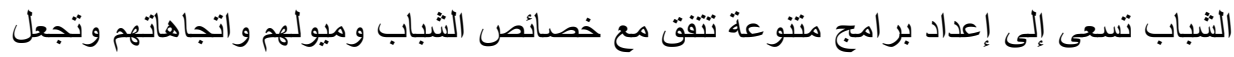

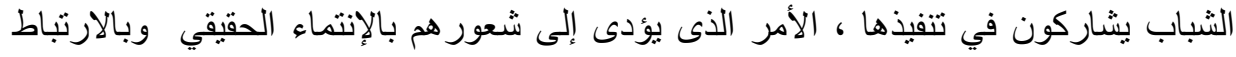

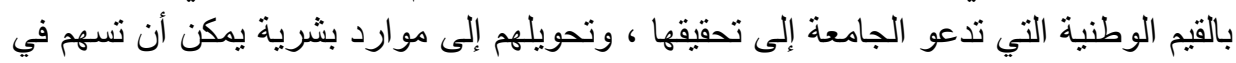

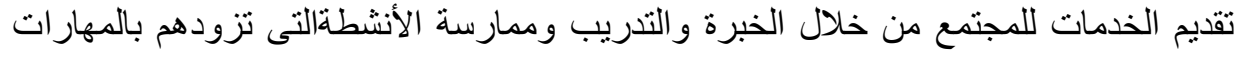

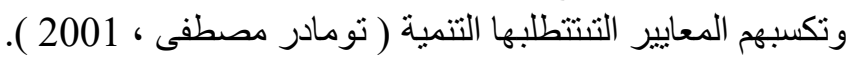

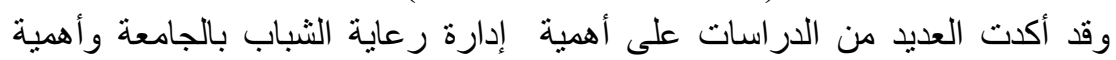

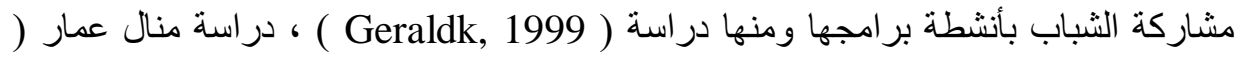

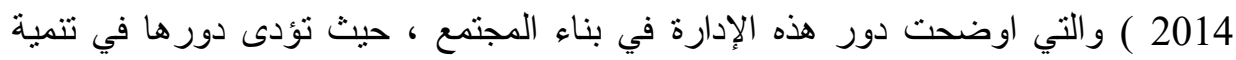

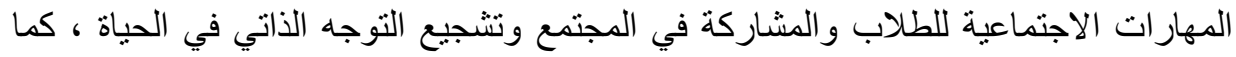

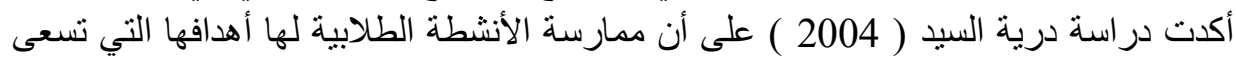

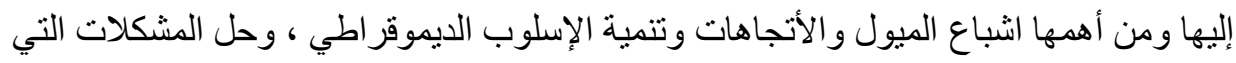




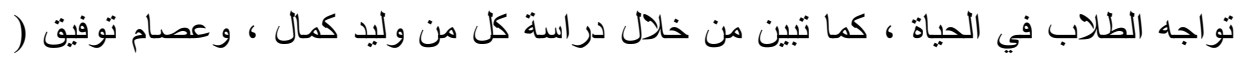

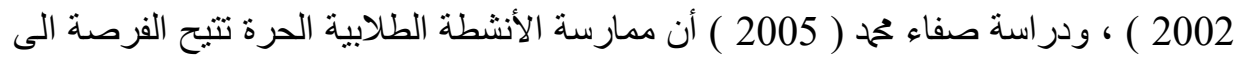

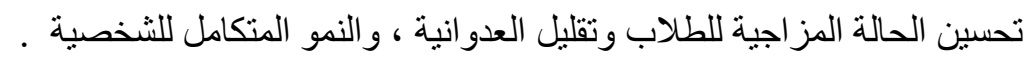

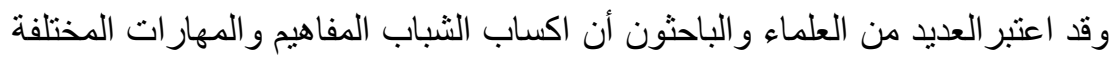

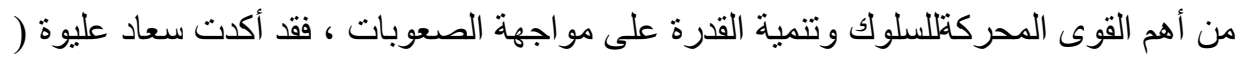

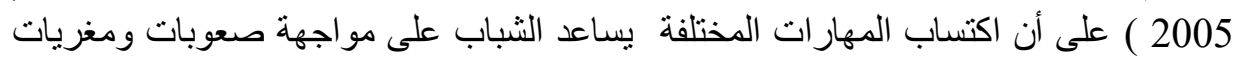

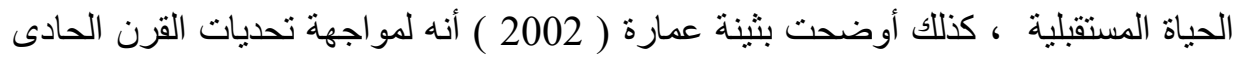

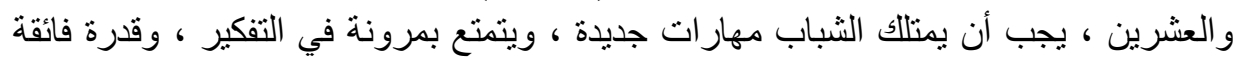

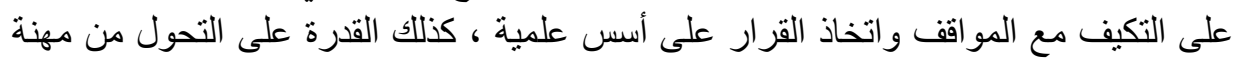

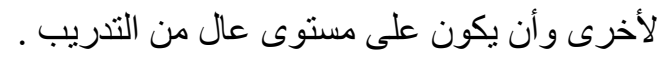

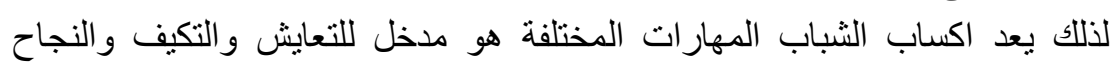

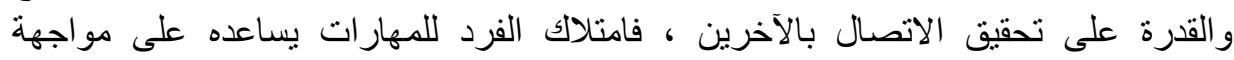

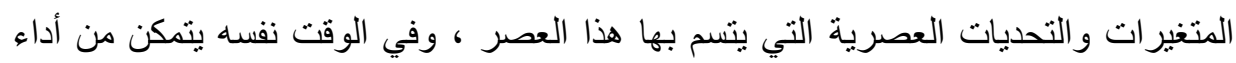

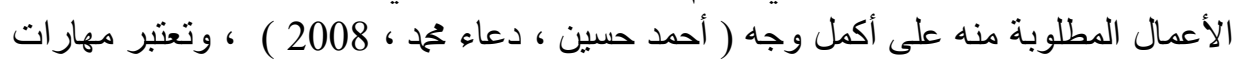

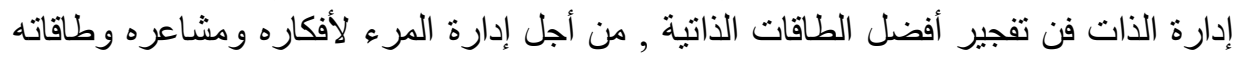

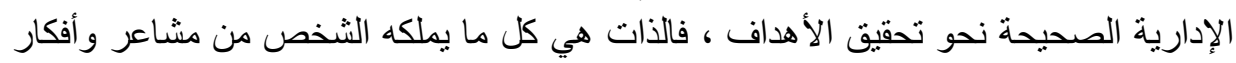

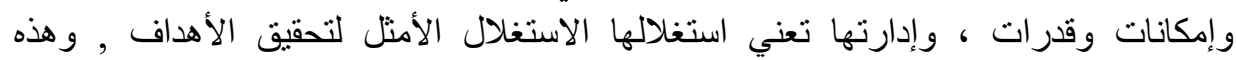

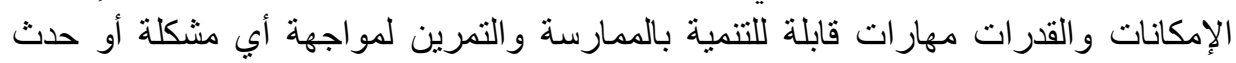

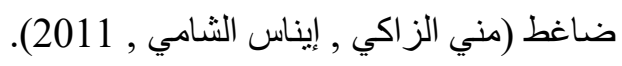
ويؤكد إبراهيم الديب ( 2009) على النيان أن الإدارة الناجحة للأذات أمر مهم وحاسم فى تحقيق

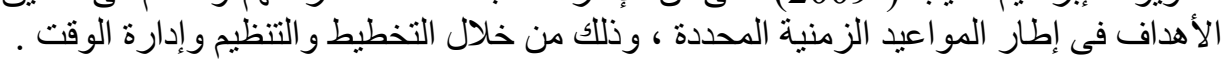

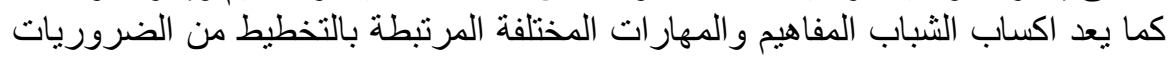

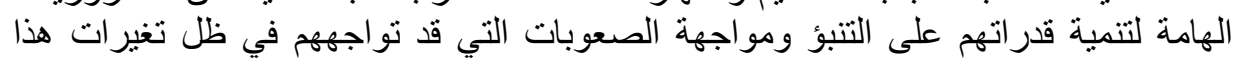

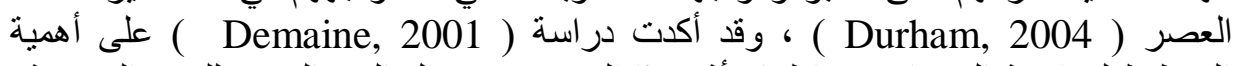
التخطيط لمواجهة التغيرات ، واظهار أثر هذا التغيير من خلال الفهم العميق للقوى التي نؤثر التر على تفكير الثباب وسلوكهم . وتأكيدا لأهمية الدور والمسئولية التى تقع على كاهل الجامعة في تقويم الثباب

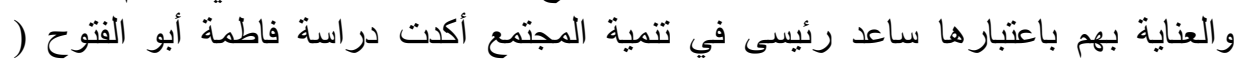

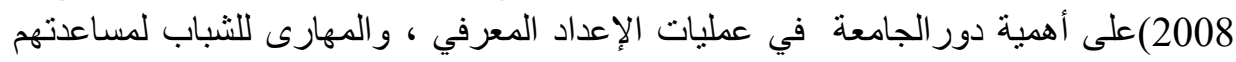

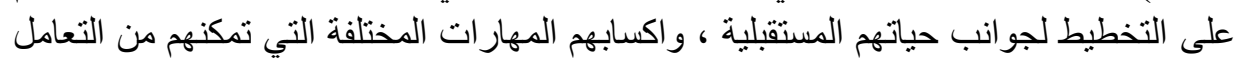

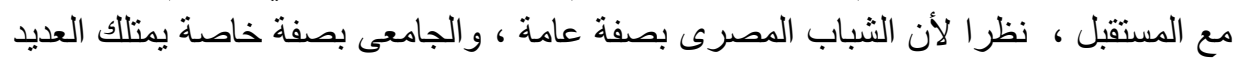

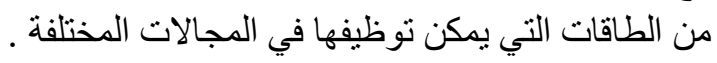

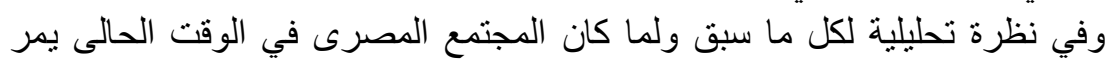

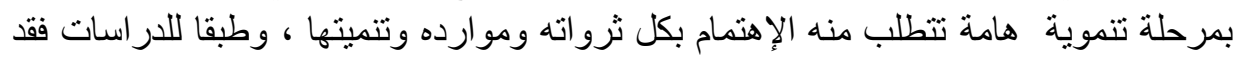


أصبح المجتمع في حاجة ماسة لوجود العديد من الوسائل التى تعمل على رفع كفاءة الثباب

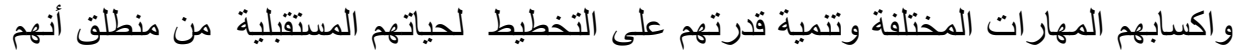

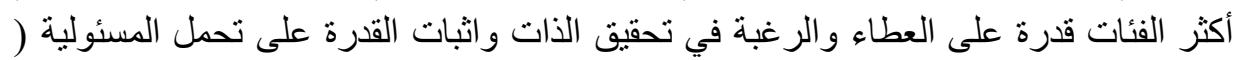

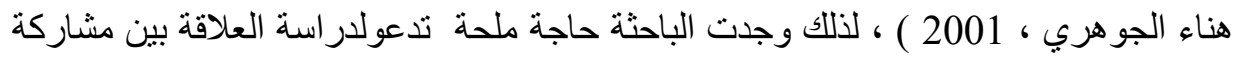

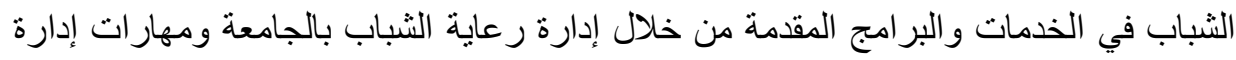

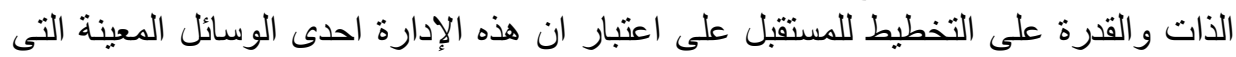

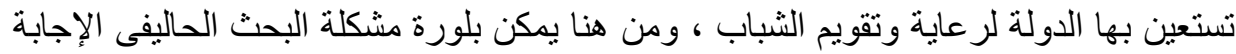

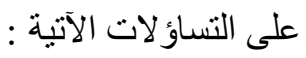

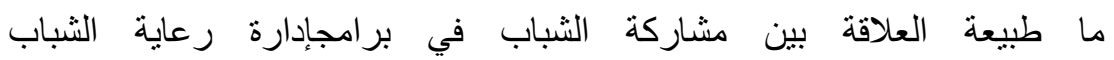
بالجامعةو مهار ات إدارة الذات والقبرة على التخطيط للمستقبل ؟

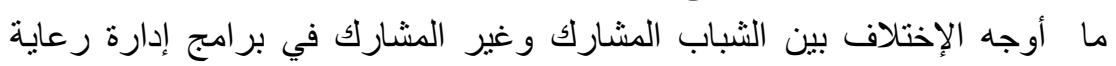

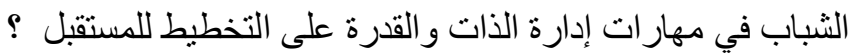

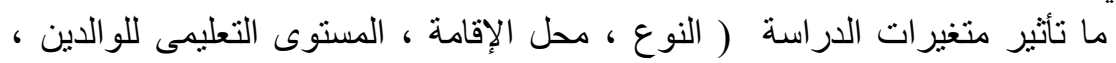

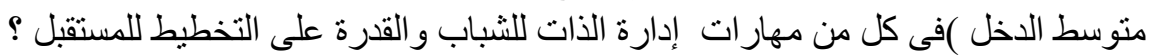

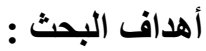

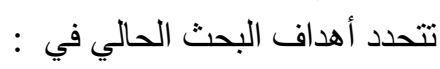
1- ايجاد الفروق بين الثباب المشارك و وغير المشارك بلير امج إدارة رعاية الثباب بالجامعة

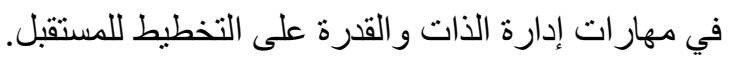

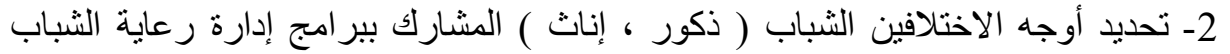
بالجامعة في مهار ات إدارة الذات و القدرة على القيل التخطيط للمستقبل.

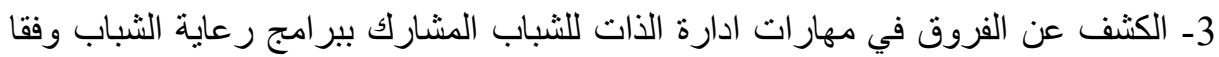

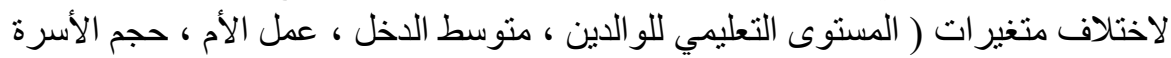

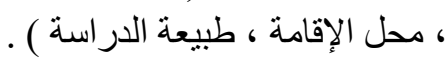
4- الكثف عن الفروق في قدرة الثباب المشارك ببر امج رعاية الثباب على التخطبط وفقا

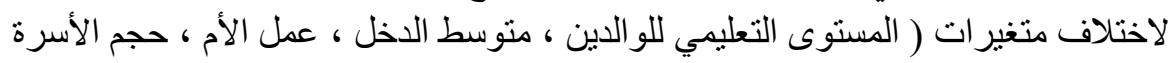

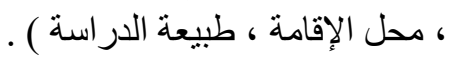

5- تحديد العلاقة بين مشاركة الثباب الجامعي ببرامج الدابل إدارة رعاية الثباب بالجامعة

$$
\text { ومهار ات ادارة الذات و القدرة على التخطيط للمستقبل. }
$$

1- إلقاء الضوء على الأثر الفعال لمنظومة الخدمات و البر امج المقدمة من خلال إدارة رعاية

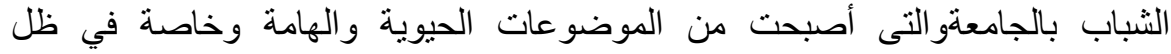

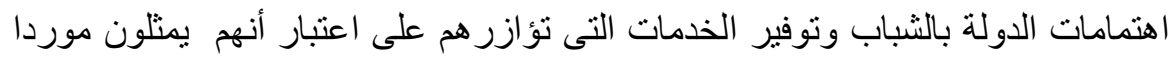

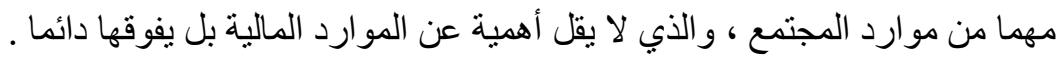


2- در اسة دور إدارة رعاية الثباب بالجامعةوفقا لنتائج البحث ، ونشر الوعي بأهمية ما يوفره

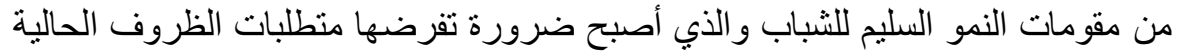
لتحقيق عملية التنمية .

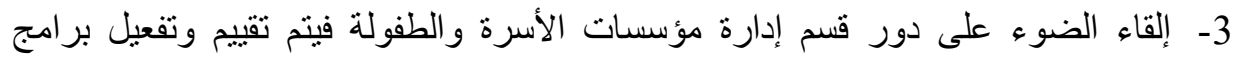

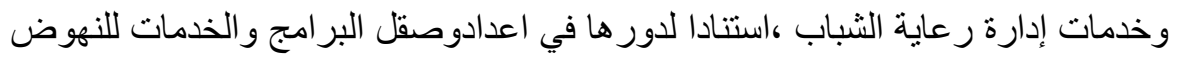

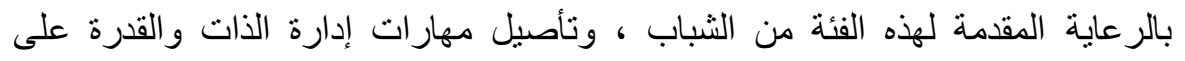

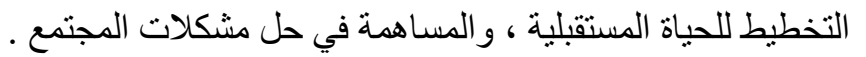

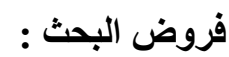
1- توجد فروق ذات دلالة إحصائية بين الثباب المشارك و غير المشارك بير امج إدارة رعاية

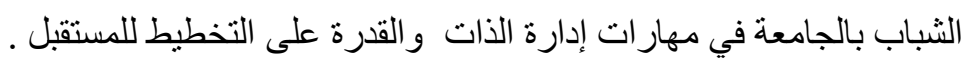

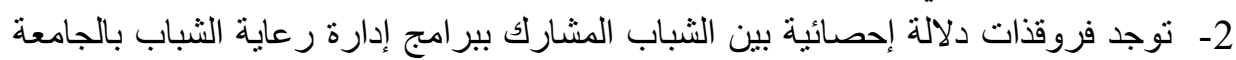

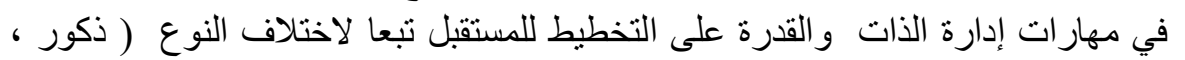

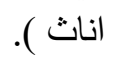
3- توجد فروق ذات دلالة إحصائية في مهار ات ادارة الذات للشباب المشارك بير امج إدارة

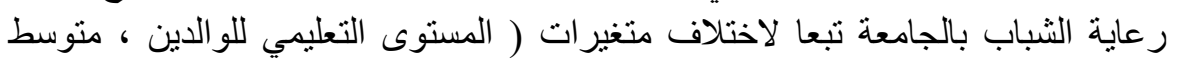

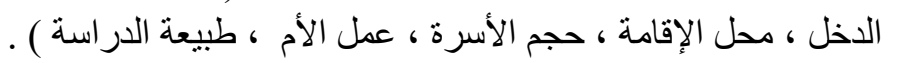

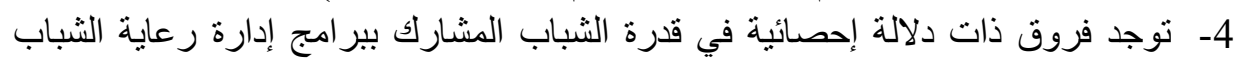

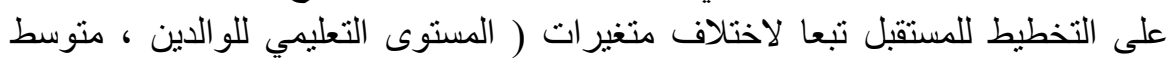

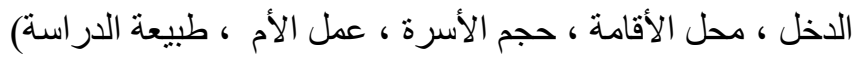

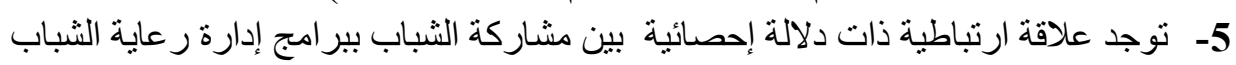

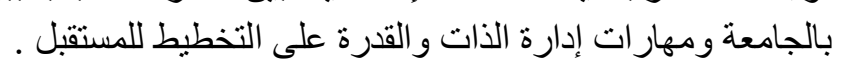

$$
\text { الأسلوب البحثي : الجمان }
$$

\section{أولا : المصطلحات العلمية والمفاهيم الإجرائية :}

المشاركة : هي قيام الفرد مع الآخرين بعمل يمليه عليه الا هتمام ويتطلبه الفهم لأعمال

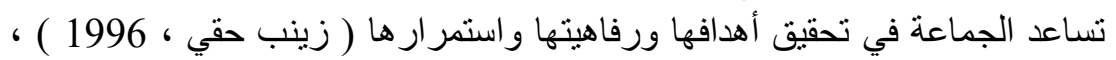

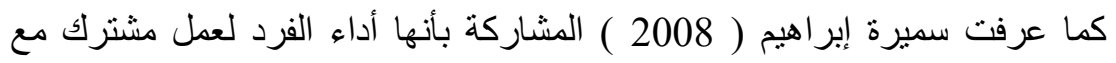

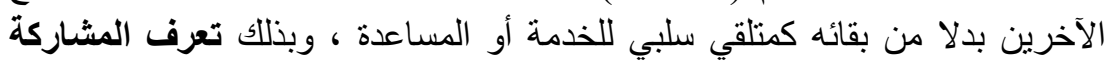

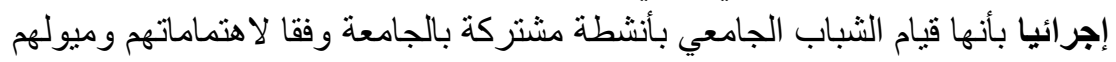

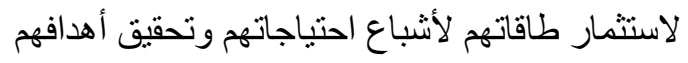

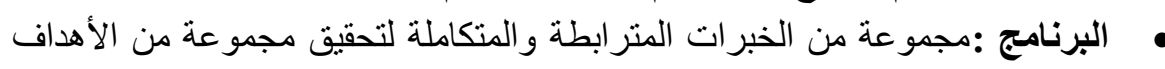

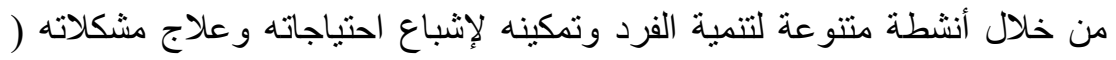
أماني عبد المقصود ، 2008 ) 
برامج إدارة رعاية الثباب : هي مجموعة من الخبرات والأنشطة المخططة والمقصودة التى واتى

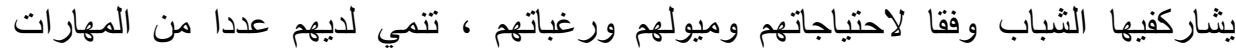

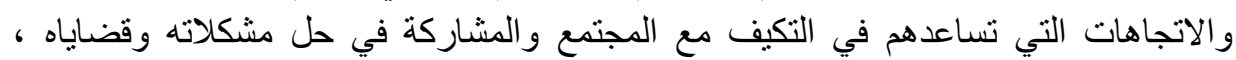

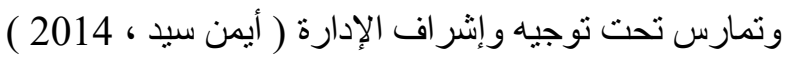

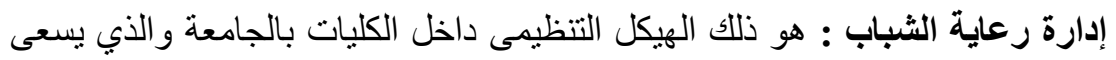

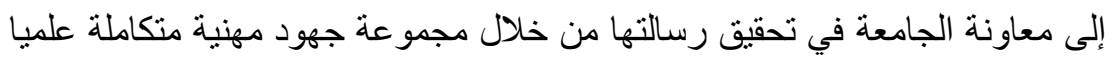

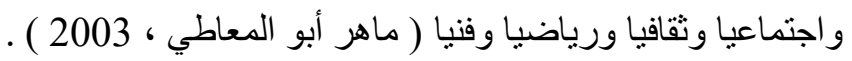

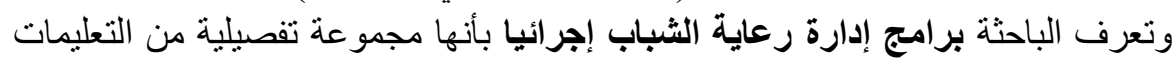

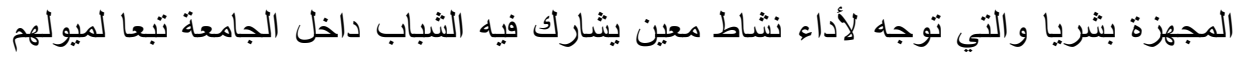

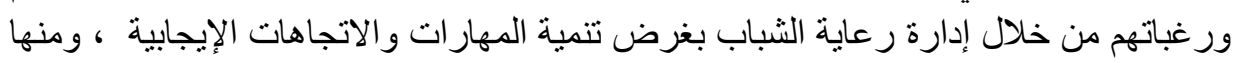

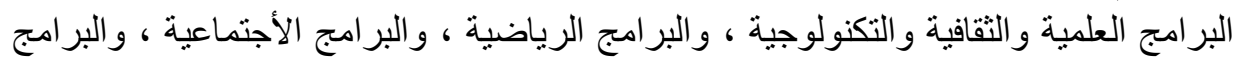

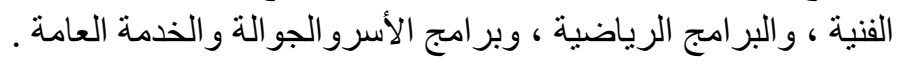

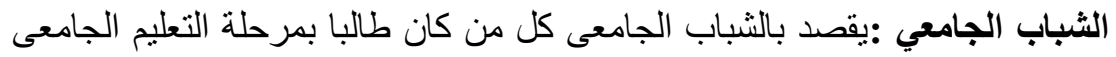

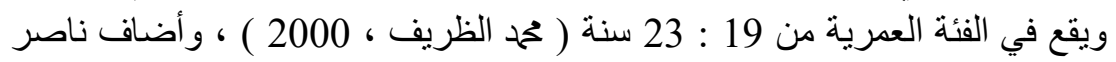

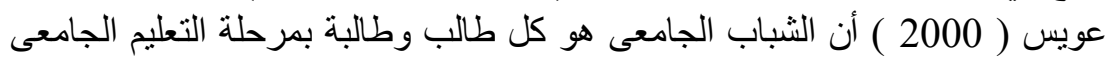

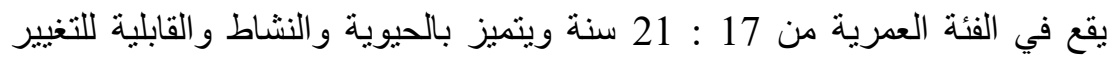

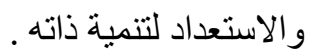

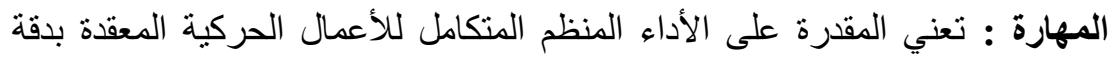

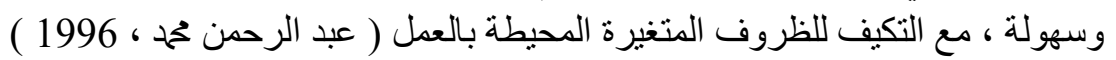

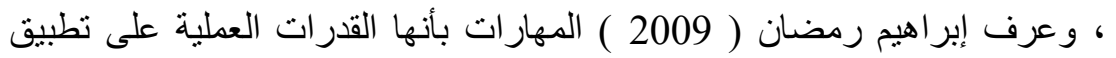

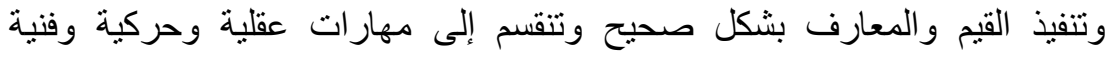

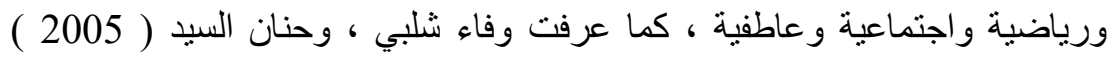

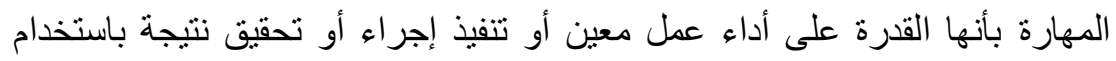
أساليب وطرق تتسم بالكفاءة والتميز بما يحقق نتائج أعلى وأفضاء أفضل مما استخدم في تلفي

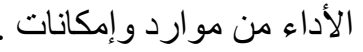

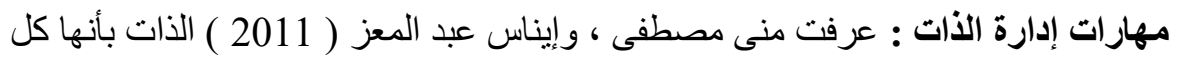

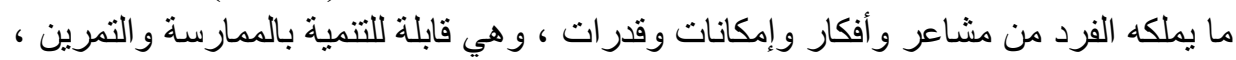

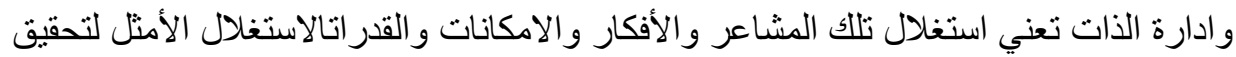

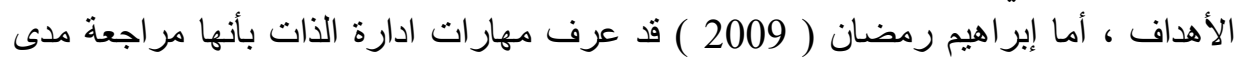

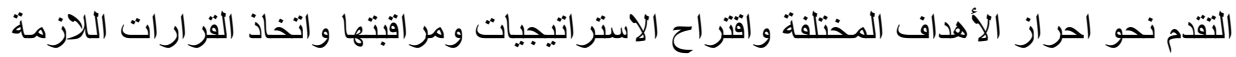

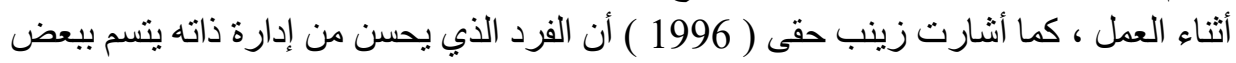

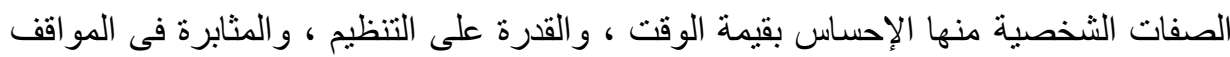

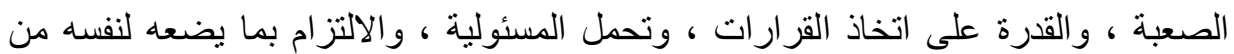


أهداف مستقبلية لتحقيق ذاته، وبذللك تعرف الباحثة مهارات إدارة الذات إجرائيا بأنها قدرة

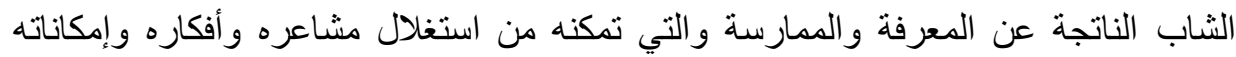

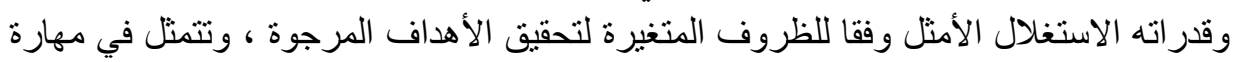

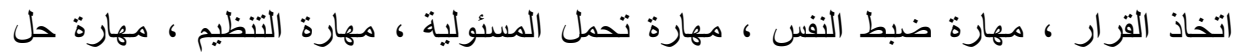

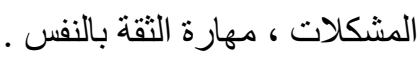

القدرة : هي إمكانية الفرد الحالية التى وصل إليها بالفعل سواء كان ذلك عن طريق

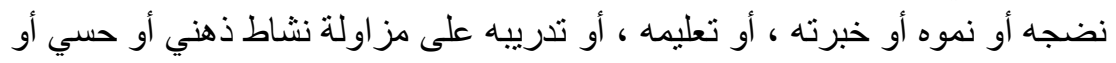

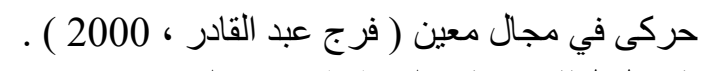

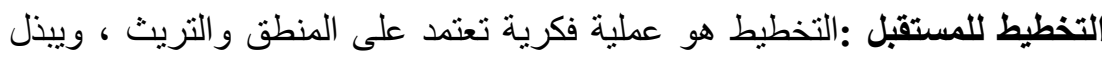

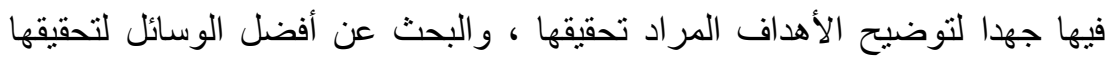

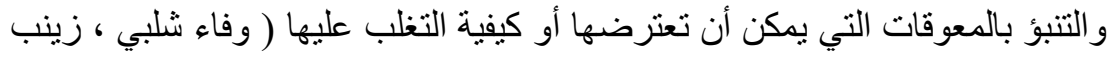

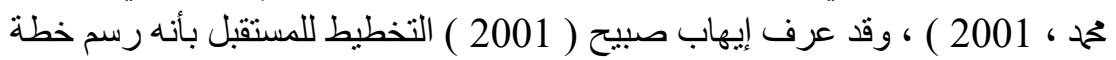

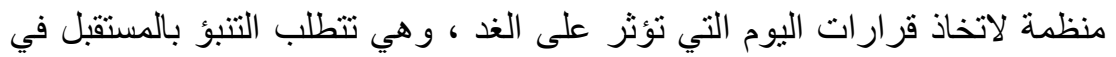

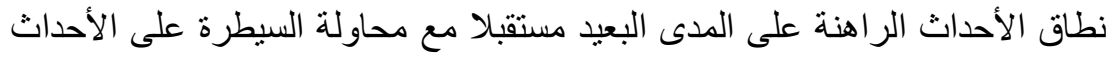

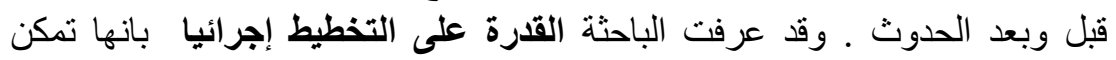

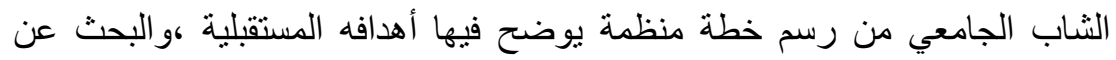

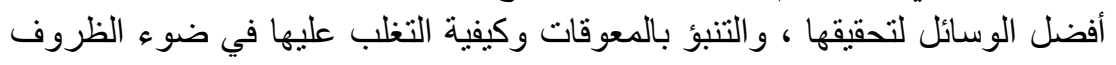

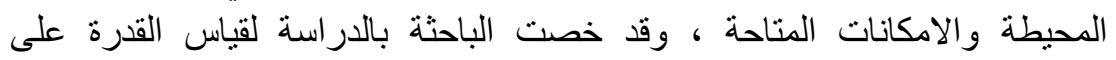

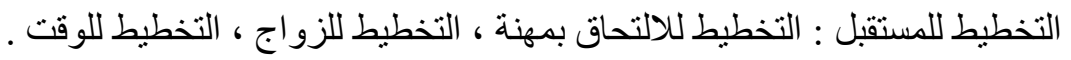
ثانيا : منهج البحث :

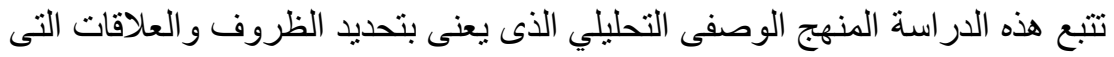

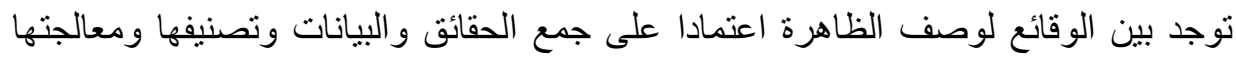

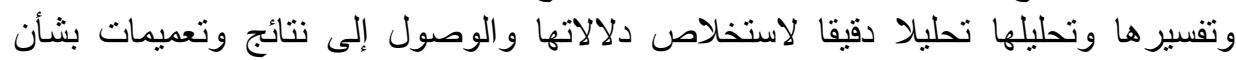

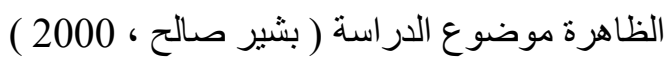

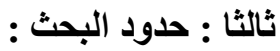

الحدود البشرية : تكونت عينة البحث من 204 شابا وفتاة في المرحلة العمرية من ( 17 :

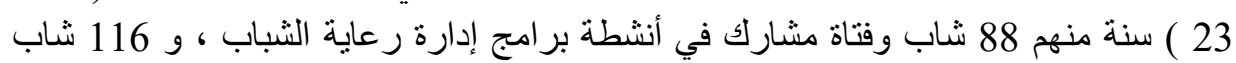

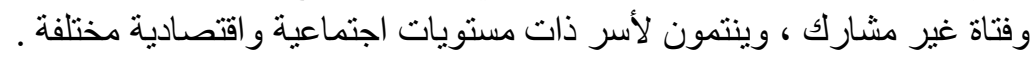

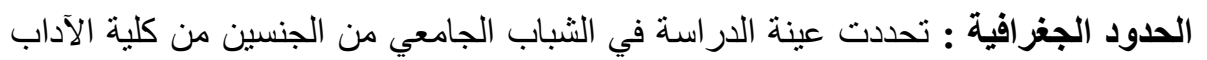

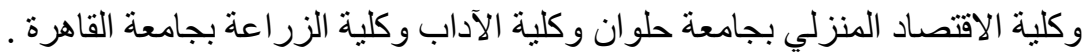

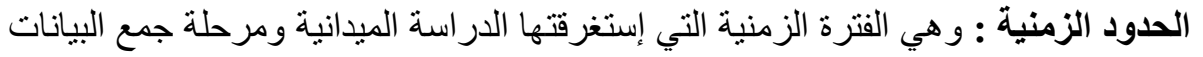

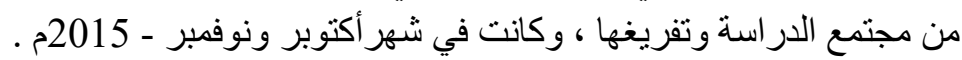

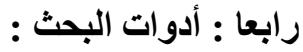


مجلة الاقتصاد المنزلى - مجلد 26 العدد الأول - 2016

1 - 1 - استمارة البيانات الاولية :

تم تقسيم هذه الإستمارة وفقا لأهداف الأف الدار استة الحالية إلى :

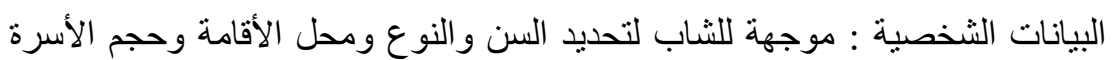

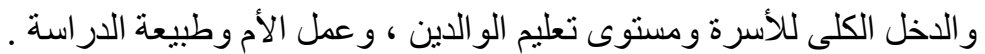

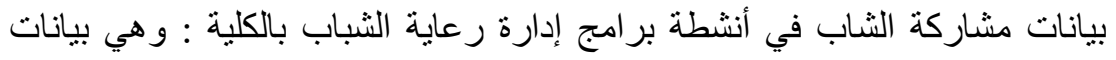

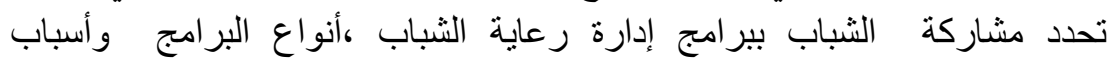

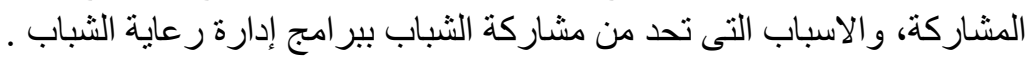

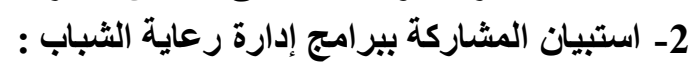

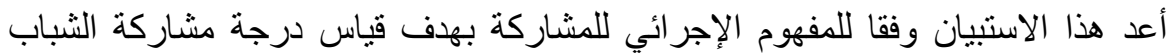

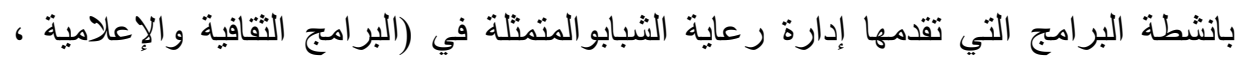

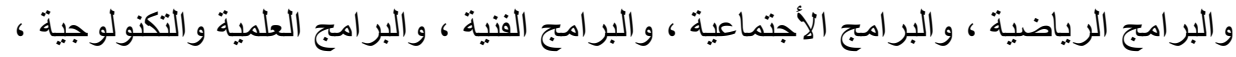

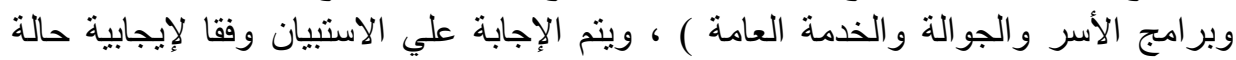

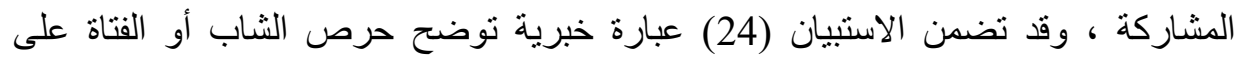

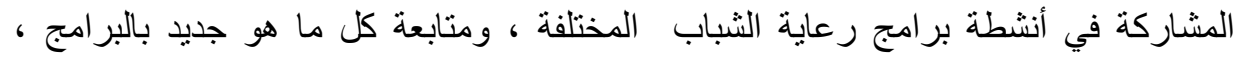

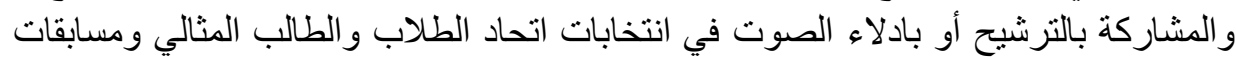

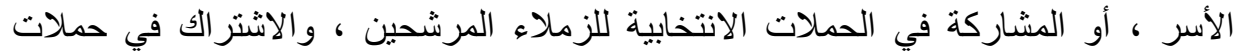

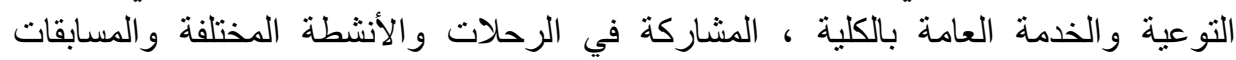

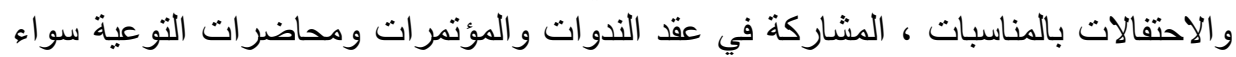

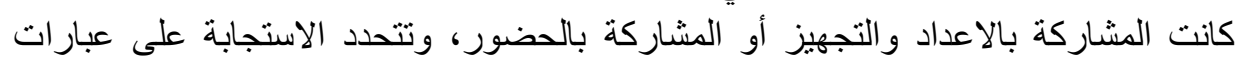

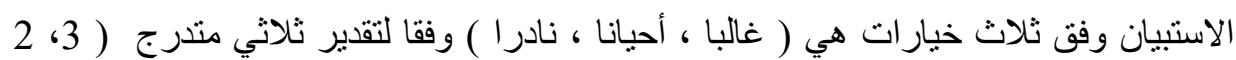

3- استبيان مهارات إدارة الذات :

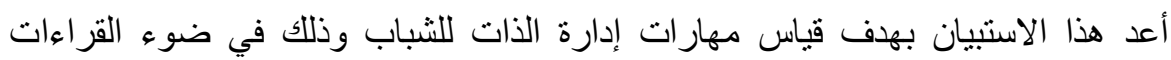

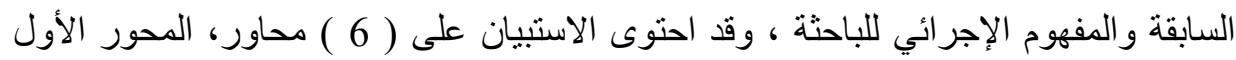

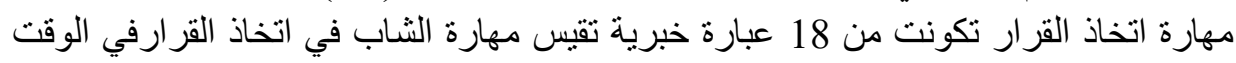

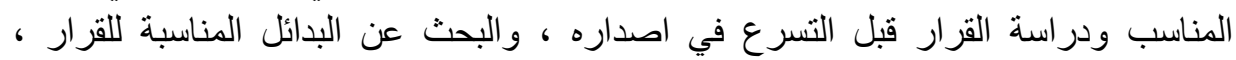

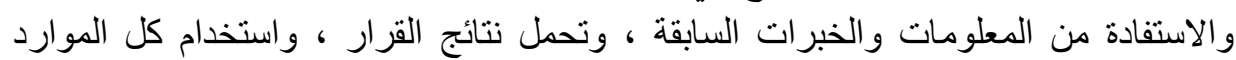

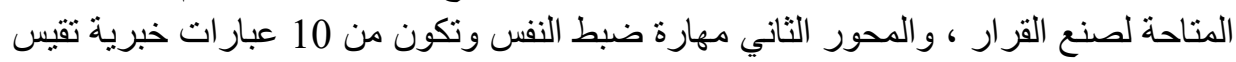

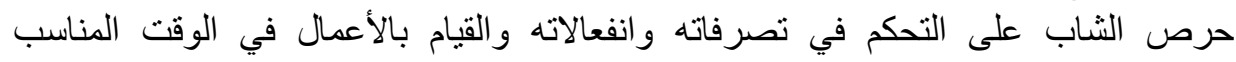

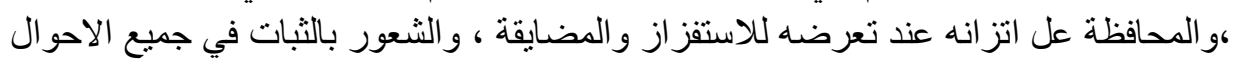

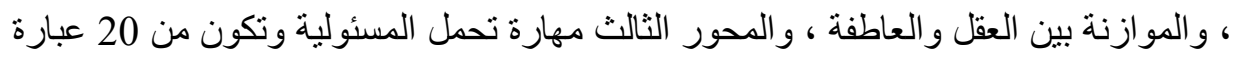

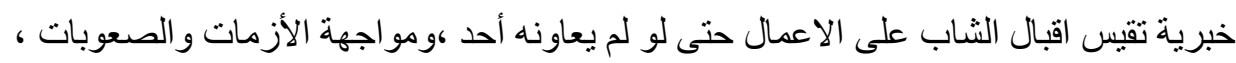

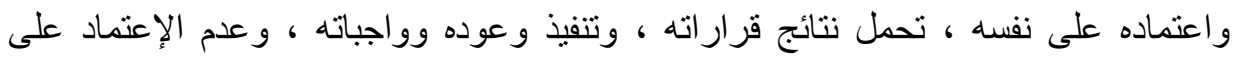




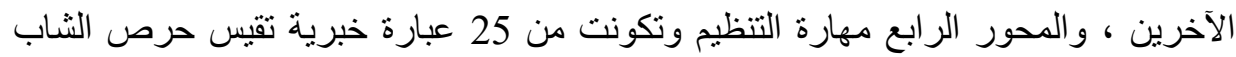

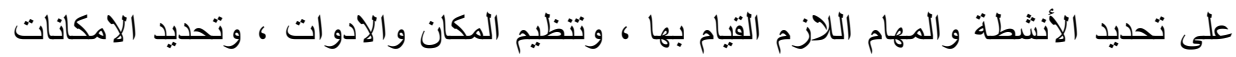

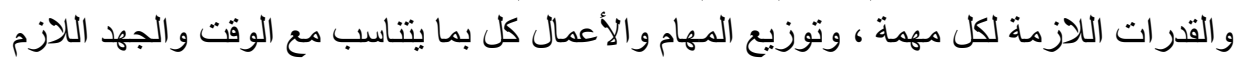

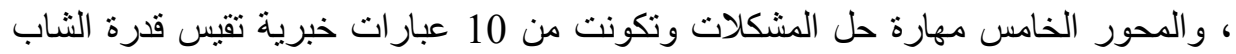

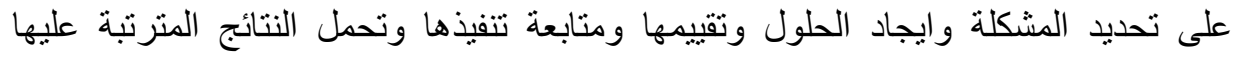

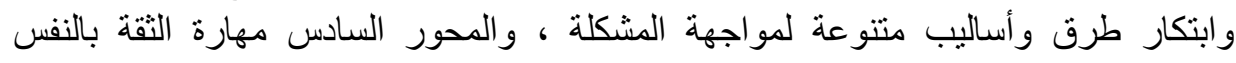

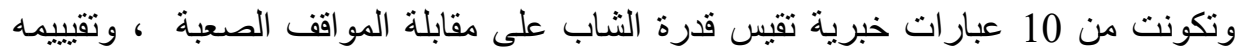

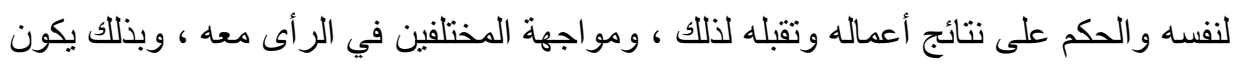

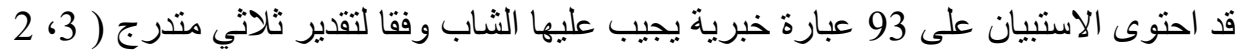

4- استبيان القدرة على التخطيط للمستقبل : وضع هذا الاستبيان بهدف قياس قدرة الثشاب على الثى التخطيط للمستقبل وبعد الاطلاع

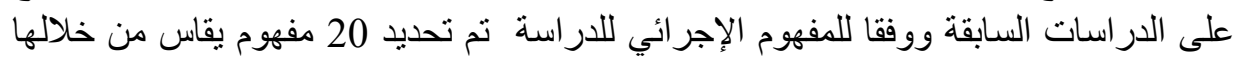

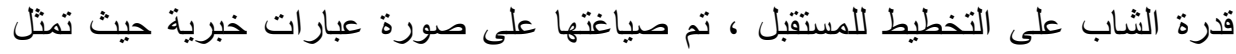

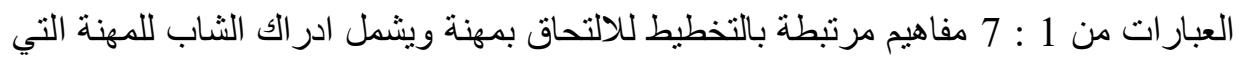

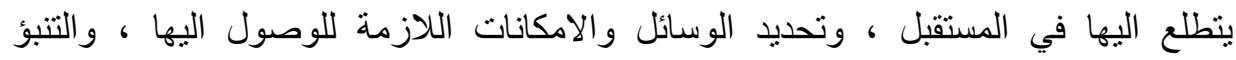

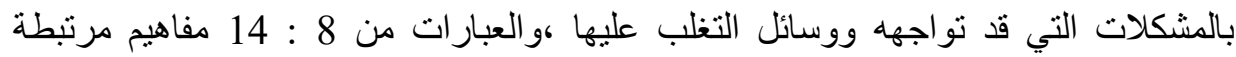

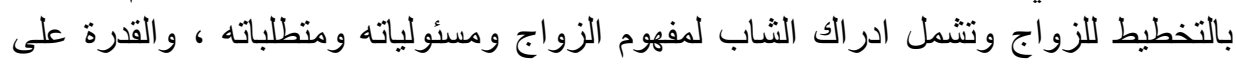

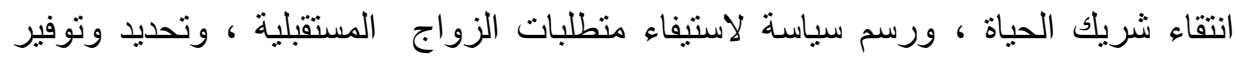

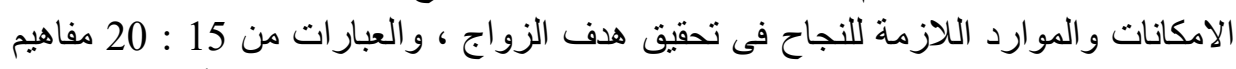

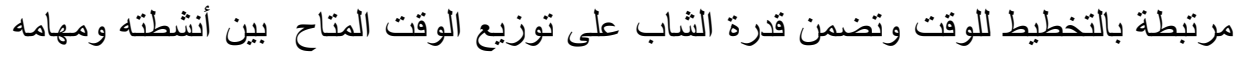

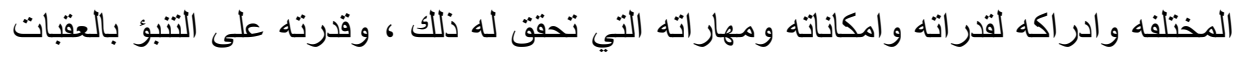

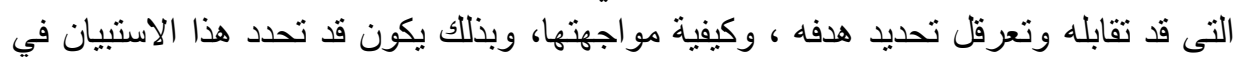

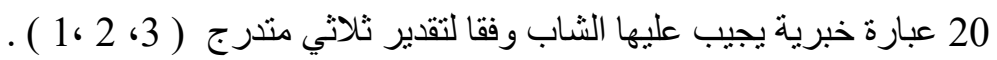

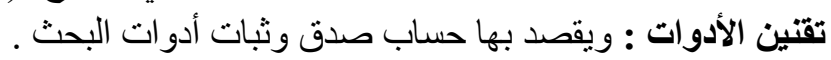

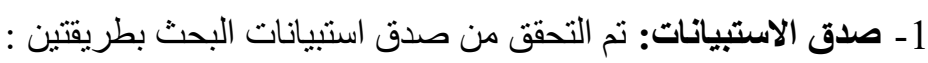

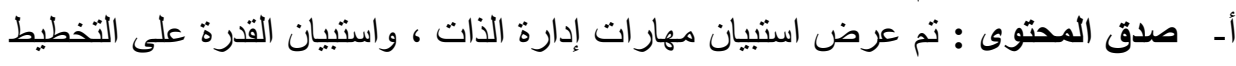

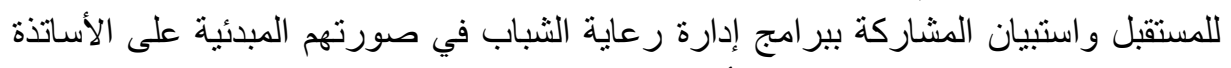

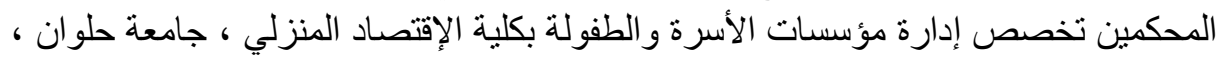

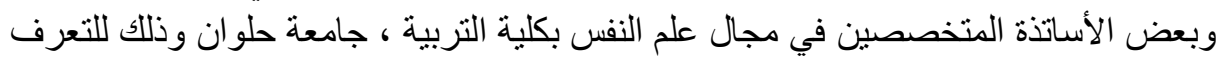

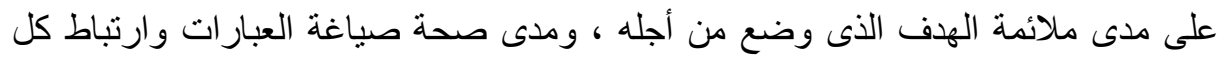
عبارة بمفهوم المحور الذى تتضمنه ، ومناسبة التقدير الذى وضع الذئ ، لكل عبارة ، وقد تبين اتفاق 
آراء المحكمين بنسبة 83 :87 \% ، كما تم إجراء بعض التعديلات على صياغة بعض العبار ات للاستبيانات .

بـ صدق الاتساق الداخلي : وذللك عن طريق حساب معات معامل ارتباط بيرسون لكل من استبيانات

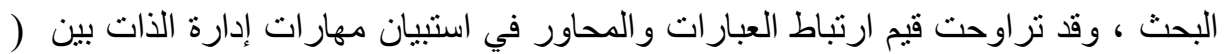

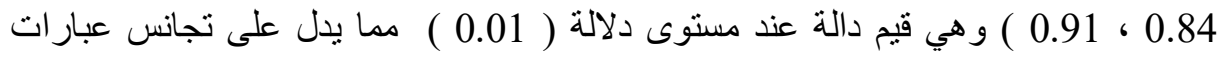

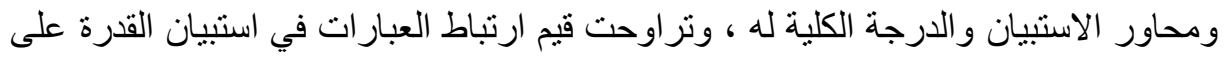

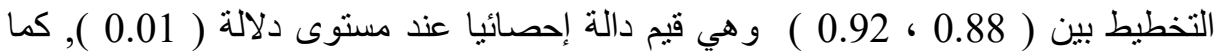

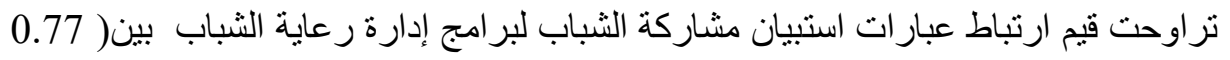

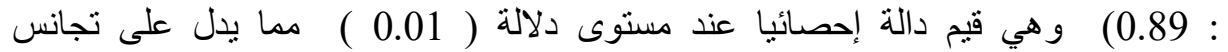

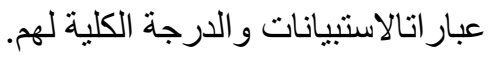

2- حساب ثبات الاستبيانات : تم حساب ثبات الاستبياناتبطريقتالفاكرونباخ و التجزئة النصفية

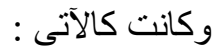

\begin{tabular}{|c|c|c|c|}
\hline \multicolumn{4}{|c|}{ جدول (1) قيم معاملات الثبات لأدوات البحث } \\
\hline معامل التجزئة النصفية & معامل الفاكرونباخ & محاور المقياس & 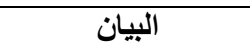 \\
\hline 0.89 & 0.93 & مهارة اتخاذ القرار & استبيان مهارات إدارة \\
\hline 0.84 & 0.87 & مهارة ضبط النفس & 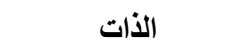 \\
\hline 0.87 & 0.89 & مهارة تحمل المسئولية & \\
\hline 0.87 & 0.91 & مهارة التنظيح & \\
\hline 0.83 & 0.86 & مهارة حل المشكلات & \\
\hline 0.86 & 0.88 & مهارات إدارة الذات ككل & \\
\hline 0.83 & 0.86 & تخطيط للمستقبل & استبياتالقدرة \\
\hline 0.82 & 0.87 & امج إدارة رعاية الثباب & استبيان مشاركة الثب \\
\hline
\end{tabular}

يتضح من جدول (1) أن جميع قيم معامل الثبات للاستبيانات كانت قيم عالية مما يدل على التى

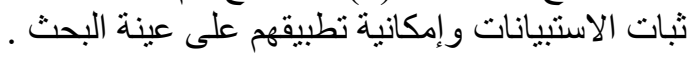

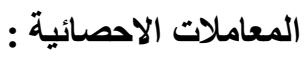

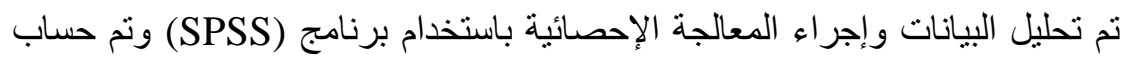

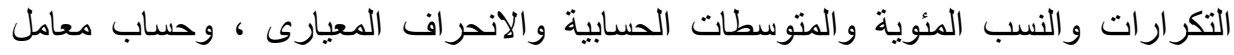

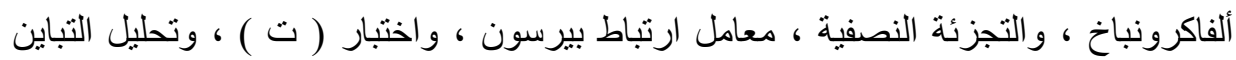

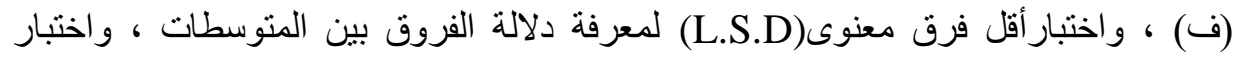

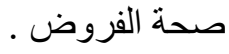


مجلة الاقتصاد المنزلى - مجلد 26 العدد الأول - 2016

$$
\begin{aligned}
& \text { نتائج الدراسة ومناقشتها : } \\
& \text { أولا : النتائج الوصفية : } \\
& \text { أ- وصف عينة الدراسة : }
\end{aligned}
$$

\begin{tabular}{|c|c|c|c|c|c|}
\hline \multicolumn{2}{|c|}{$\begin{array}{c}\text { الثباب غير المشارك (116) } \\
\text { (116 }\end{array}$} & \multicolumn{2}{|c|}{$\begin{array}{c}\text { الثباب المشارك=(88) } \\
\text { (88) }\end{array}$} & \multirow[t]{2}{*}{ الفئة } & \multirow{2}{*}{ الاراسيرة } \\
\hline$\%$ & العدد & $\%$ & العدد & & \\
\hline 58.6 & 68 & 60.2 & 53 & ذكر & \multirow[t]{2}{*}{ النوع النوع } \\
\hline 41.4 & 48 & 39.8 & 35 & 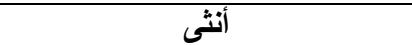 & \\
\hline 47.4 & 55 & 38.6 & 34 & من 17 : 20 سنة & \multirow[t]{2}{*}{ السن } \\
\hline 52.6 & 61 & 61.4 & 54 & من 20: إ 23 سنة & \\
\hline 50.9 & 59 & 46.6 & 41 & حلوان & \multirow[t]{2}{*}{ الجامعة } \\
\hline 49.1 & 57 & $\overline{53.4}$ & 47 & 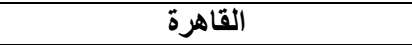 & \\
\hline 48.3 & 56 & 37.5 & 33 & نظرية & \multirow{2}{*}{ الدراسة } \\
\hline 51.7 & 60 & 62.5 & 55 & عملية & \\
\hline 77.6 & 90 & 45.5 & 40 & حضر & \multirow{2}{*}{ الإقامة } \\
\hline 22.4 & 26 & 54.5 & 48 & ريف & \\
\hline 20.7 & 24 & 7.9 & 7 & صغير(3 : 4 أفراد) & \multirow{3}{*}{ الأسجرة } \\
\hline 31.0 & 36 & 43.2 & 38 & متوسط ( من 5: 6 أفراد ) & \\
\hline 48.3 & 56 & 48.9 & 43 & كبير (أكثر من 6 أفراد ) & \\
\hline 45.7 & 53 & 56.8 & 50 & عاملة & \multirow[t]{2}{*}{ 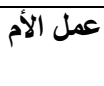 } \\
\hline 54.3 & 63 & 43.2 & 38 & غير عاملة & \\
\hline 14.6 & 17 & 27.3 & 24 & منذفض (إعدادية فأقلّ) & \multirow{3}{*}{ التلأليمي } \\
\hline 39.7 & 46 & 35.2 & 31 & متوسط (ثانوية،فوفق المتوسط) & \\
\hline 45.7 & 53 & 37.5 & 33 & عالي (جامعي،فوق جامعي) & \\
\hline - & - & - & - & منخفض(إعادية فأقلّ) & \multirow{3}{*}{ التلابيمي } \\
\hline 31.1 & 36 & 35.2 & 31 & متوسط(ثانوية'،فوق المتوسط) & \\
\hline 68.9 & 80 & 64.8 & 57 & عالي(جامعي،فوق جامعي) & \\
\hline 31.1 & 36 & 29.5 & 26 & منخفض ( أقل من 1500 جنيه ) & \multirow{3}{*}{ الثتول } \\
\hline 48.2 & 56 & 30.7 & 27 & متوسط ( من 1500 : 3000 جنيه ) & \\
\hline 20.7 & 24 & 39.8 & 35 & مرتفع ( أكثر من 3000 جنيه ) & \\
\hline
\end{tabular}

جدول (2) توزيع أفراد عينة الدراسة وفقا لمتفيرات الدراسة (ن=204)

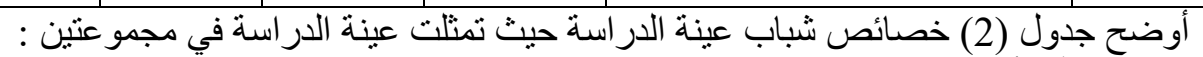

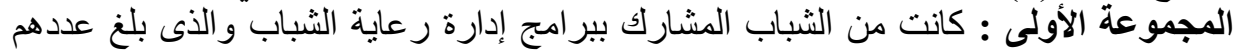

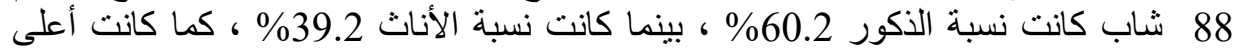

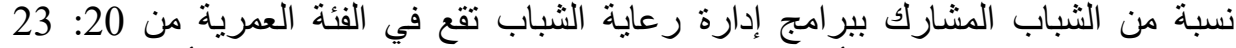

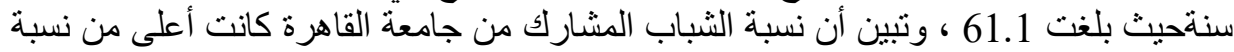

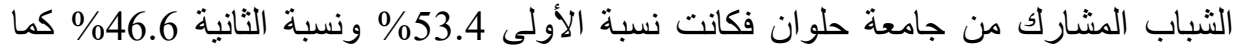
تفوقت نسبة الثباب المشارك بالكليات العملية مقارنة بنسبة الثباب المشارك بالكليات النظرية 
مجلة الاقتصاد المنزلى - مجلد 26 العدد الأول - 2016

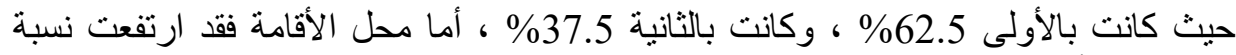

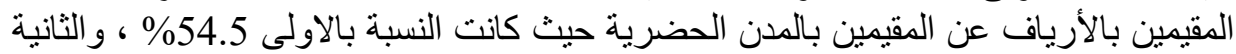

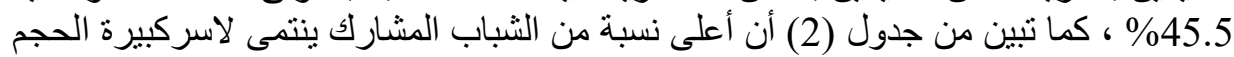

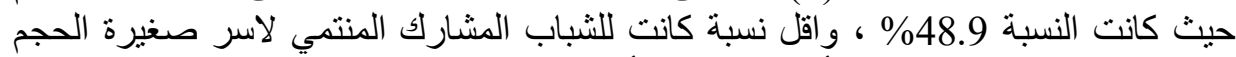

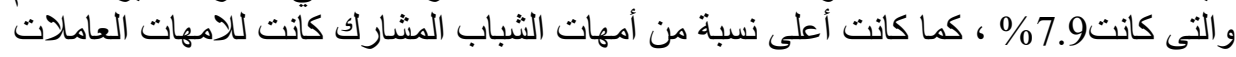

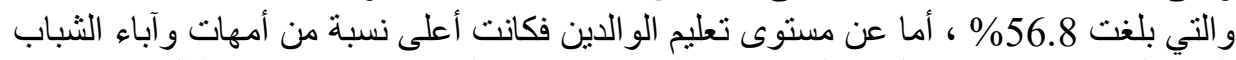

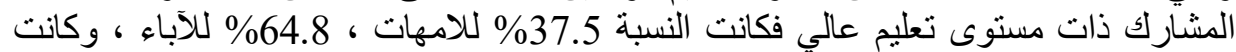

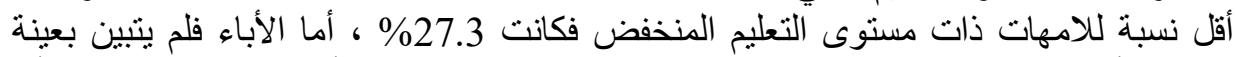

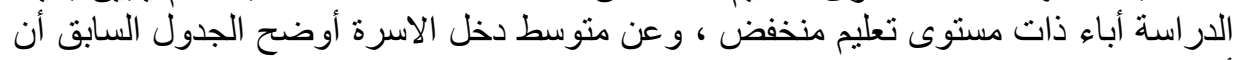

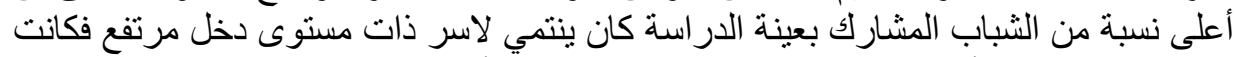

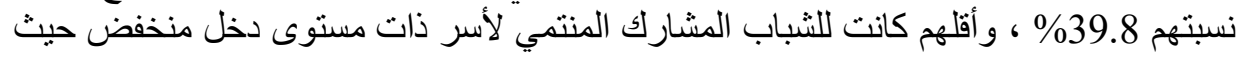
كانت نسبتهم 29.5\%

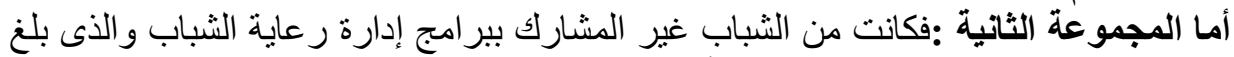

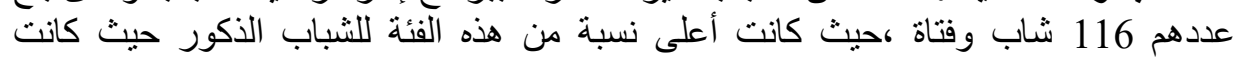

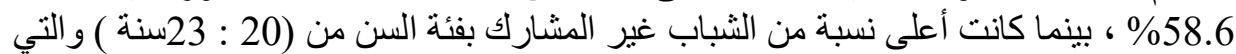

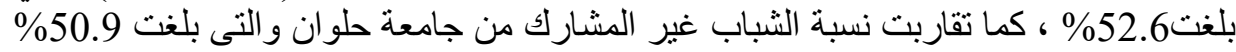

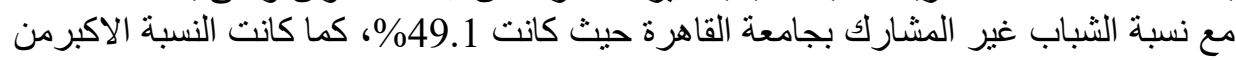

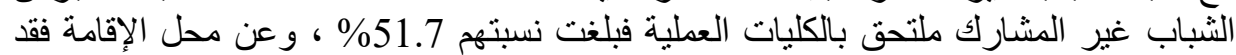

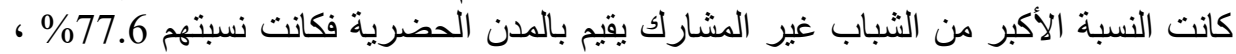

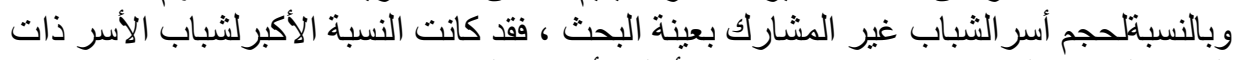

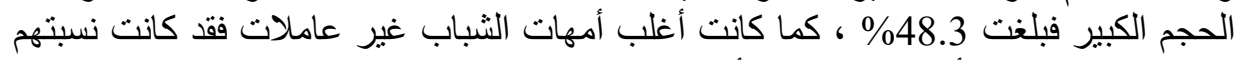

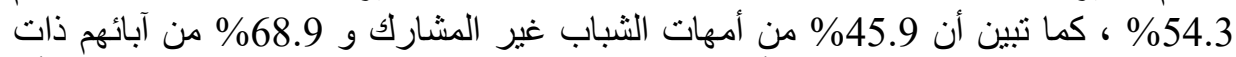

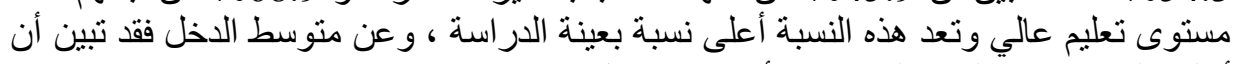

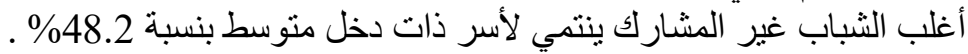
ب_مستوى مهارات الثباب في إدارة الذات بعينة البات البحث : جدول (3) توزيع عينة البحث تبعا لمستوى مهار البحث : بات إدارة الذات

\begin{tabular}{|c|c|c|c|c|c|c|c|}
\hline$\%$ & التكرار & مستوى المدى & ( بالارجات ) & طولة الفئة & المدى & العبارات & البيانات \\
\hline 9,1 & 8 & منخفض & 185 - 200 درجة & \multirow[t]{3}{*}{15} & \multirow[t]{3}{*}{45} & \multirow[t]{3}{*}{93} & \multirow{3}{*}{ الثبراب إلبارة رعارية } \\
\hline 44.3 & 39 & متوسط & 201 - 216 درجة & & & & \\
\hline 46.6 & 41 & مرتفع & 216 درجة فأكثر & & & & \\
\hline 44.8 & 52 & منذفض & 170 - 178 درجة & \multirow[t]{3}{*}{8} & \multirow[t]{3}{*}{24} & \multirow[t]{3}{*}{93} & \multirow{3}{*}{ المشاركب بيراميرج } \\
\hline 39.7 & 46 & متوسط & 179 - 187 درجةً & & & & \\
\hline 15.5 & 18 & مرتفع & 187درجةَة فَأكثر & & & & \\
\hline
\end{tabular}

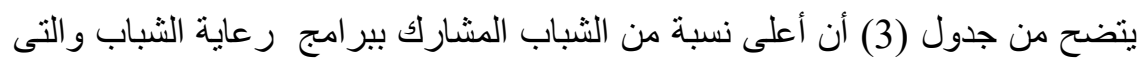

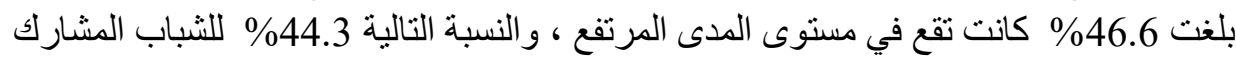


كانت تقع في مستوى المدى المتوسط و هذا يعنى أن مستوى الثباب المشاركبير امج ر رعاية

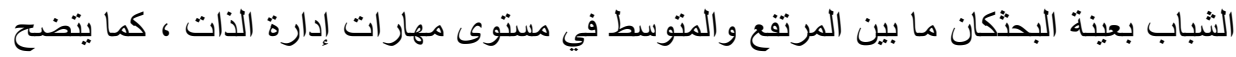

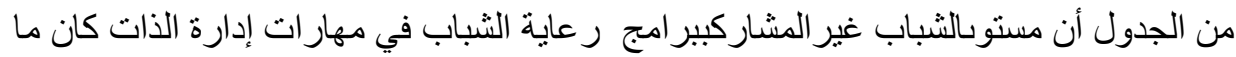

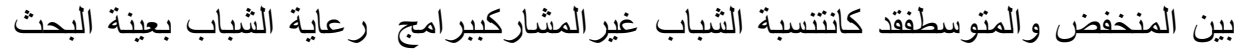

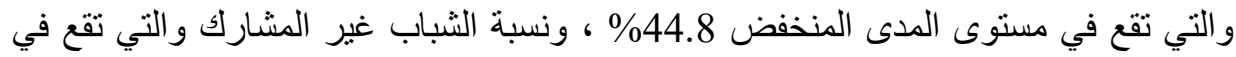

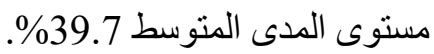
ج- مستوى الثباب في القدرة على التخطيط للمستقبل : جدول (4) توزيع عينة البحث تبعا لمستوى القدرة على التخطيط للمستقبل

\begin{tabular}{|c|c|c|c|c|c|c|c|}
\hline$\%$ & التكرار & مستوى المدى & ( بالدرجات ) & الفئة & المدى & العبارات & البيانات \\
\hline 7.9 & 7 & منخفض & 42 - 46 درجة & \multirow[t]{3}{*}{4} & \multirow[t]{3}{*}{12} & \multirow[t]{3}{*}{20} & الشباب \\
\hline 22.7 & 20 & متوسط & 47 - 51 درجة & & & & المشارك ببرامج \\
\hline 69.4 & 61 & مرتفع & 51 درجة فأكثر & & & & إلشارة رعاية \\
\hline 30.2 & 35 & منخفض & 38 - 42 درجة & \multirow[t]{3}{*}{4} & \multirow[t]{3}{*}{12} & \multirow[t]{3}{*}{20} & \multirow{3}{*}{ المشارك ببراب غيرج الشبابر } \\
\hline 47.4 & 55 & متوسط & 43 - 47 درجة & & & & \\
\hline 22.4 & 26 & مرتفع & 48 درجة فأكثر & & & & \\
\hline
\end{tabular}

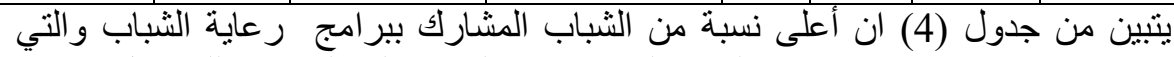

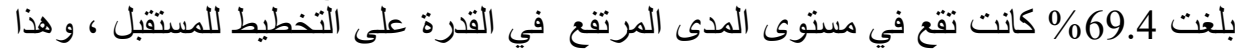

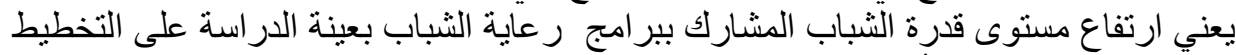

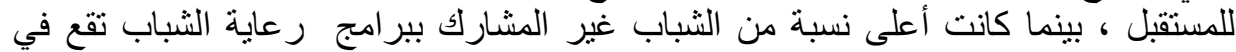

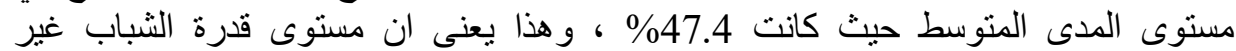

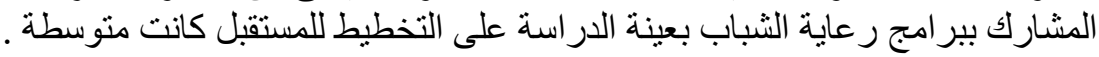
دمشاركة الثباب ببرامج إدارة رعاية الثباب :

جدول (5) نسبة مشاركة الشباب بالبرامج المختلفة لإدارة رعاية الشباب (ن=88)

\begin{tabular}{|c|c|c|c|c|c|c|c|}
\hline$\%$ & ك & أنواع البرامج & p & $\%$ & كا & أنواع البرامج & م \\
\hline 35.2 & 31 & البرامج العلمية والتكنولوجية & 5 & 48.9 & 43 & البرامج الرياضية & 1 \\
\hline 76.1 & 67 & برامج الجوالة والخدمة العامة & 6 & 30.7 & 27 & البرامج الثقافية والإعلامية & 2 \\
\hline \multirow[t]{2}{*}{64.8} & \multirow[t]{2}{*}{57} & \multirow[t]{2}{*}{ برامج الأسر ب } & \multirow[t]{2}{*}{7} & 42.1 & 37 & البرامج الإجتماعية & 3 \\
\hline & & & & 38.6 & 34 & البرامج الفنية & 4 \\
\hline
\end{tabular}

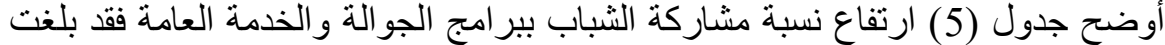

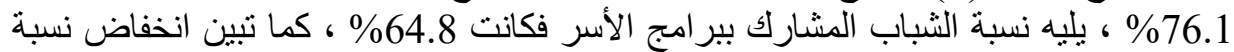

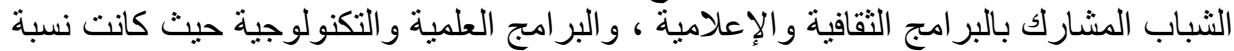

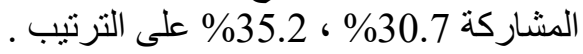


مجلة الاقتصاد المنزلى - مجلد 26 العدد الأول - 2016

هـ ـ أسباب إقبال الشباب علنالمشاركة ببرامج إدارة رعاية الثباب :

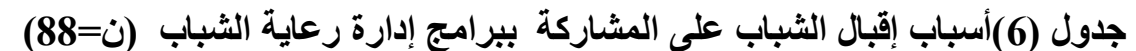

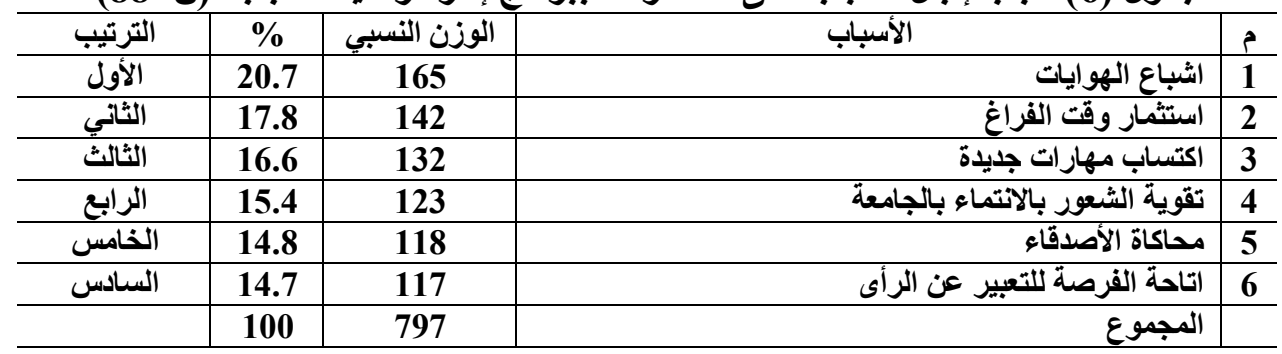

يتضح من جدول (6) أن أول أسباب إقبال الشباب على المشاركة ببرامج إدارة رعاية

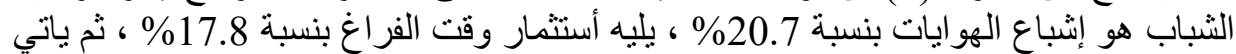

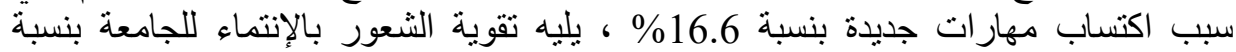

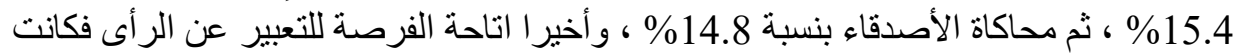

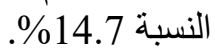

و- الأسباب التي تحد من مشاركة الثباب في برامج إدارة رعاية الشباب :

\begin{tabular}{|c|c|c|c|c|}
\hline الترتيب & $\%$ & الوزن النسبي & الأسباب & م \\
\hline الأول & 21.4 & 354 & إنشغال الثباب بالاراسة & 1 \\
\hline الثاني & 20.9 & 347 & علدم وضوح أهداف برامج رعاية الثباب & 2 \\
\hline الثالث & 19.7 & 327 & علم تو افرالأعلان الكافي عن البرامج لجذب الثباب & 3 \\
\hline الرابع & 19.1 & 315 & عدم توافر المتخصصين القائمين بتدريب الثباب & 4 \\
\hline الخامس & 18.9 & 313 & ضعف الامكانات والتجهيزات اللازمة لممارسة الأنثطة & 5 \\
\hline & 100 & 1656 & 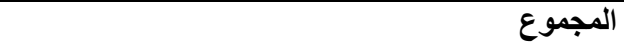 & \\
\hline
\end{tabular}

تبين من جدول (7) أن من أهم الأسباب التي تحد من مشاركة الثباب في برامج إدارة

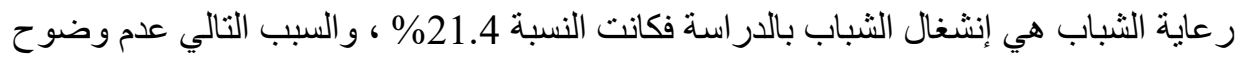
أهداف بر امج رعاية الثباب فقد كانت النسبة 20.9\% ، ثم سبب عدم تو الفر الأعلان الكافي عن

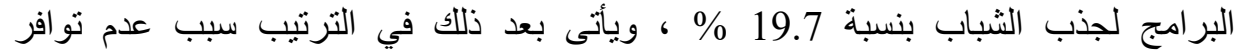

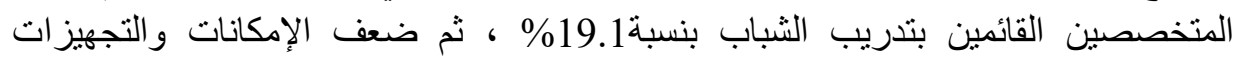

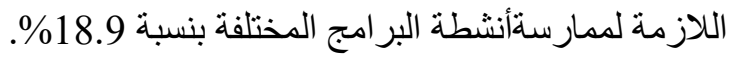


مجلة الاقتصاد المنزلى - مجلد 26 العدد الأول - 2016

ثانيا : النتائج على ضوء الفروض : الفرض الأول :توجد فروق ذات دلالة إحصائية بين الشباب المشارك وغير المشارك بيرامج إدارة ر عاية الثباب بالجامعة في مهار ات إدارة الذات و والقدرة على التخطبط للمستقبل .

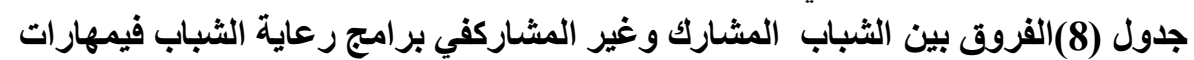

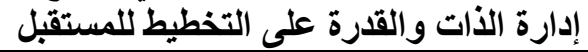

\begin{tabular}{|c|c|c|c|c|c|c|c|c|c|}
\hline \multirow[t]{2}{*}{ الالالة } & \multirow[t]{2}{*}{ قيمة (ت) } & \multicolumn{3}{|c|}{ الشباب غير المشارك } & \multicolumn{3}{|c|}{ الشباب المشارك } & \multicolumn{2}{|c|}{ المتغيرات } \\
\hline & & |المعيارى الخطأ & الالمعيارى & الحستوسي & المعيارى & الالانحراف & الحستوسي & & \\
\hline 0.001 & 6.25 & 0.26 & 2.1 & 32.1 & 0.30 & 3.6 & 34.6 & اتخاذ القرار & مهارات \\
\hline 0.001 & 8.76 & 0.13 & 1.3 & 11.9 & 0.15 & 1.6 & 13.7 & ضبط النفس & \\
\hline 0.001 & 16.16 & 0.26 & 2.7 & 38.4 & 0.31 & 3.1 & 44.9 & تحمل السئولية & \\
\hline 0.001 & 25.73 & 0.21 & 2.2 & 54.0 & 0.24 & 2.4 & 62.4 & التنظيم & \\
\hline غير دالة & 1.08 & 0.22 & 2.4 & 22.4 & 0.25 & 2.3 & 22.7 & حل المشكلات & \\
\hline 0.001 & 9.2 & 0.14 & 1.1 & 20.8 & 0.16 & 1.9 & 22.8 & الثقة بالنفس & \\
\hline 0.001 & 16.15 & 0.90 & 6.9 & 179.6 & 1.01 & 11.9 & 201.2 & المهارات ككل & \\
\hline 0.001 & 4.01 & 0.29 & 3.4 & 44.8 & 0.33 & 2.6 & 46.6 & ط اللمستقبل & التخطيص \\
\hline
\end{tabular}

يوضح جدول (8) وجود فروق ذات دلالة إحصائية بين الثباب المشاركوغير

المشارك ببر امج إدارة ر عاية الثباب بالجامعة في مهار ات إدارة الذات ككل ، و أبعادها (مهارة

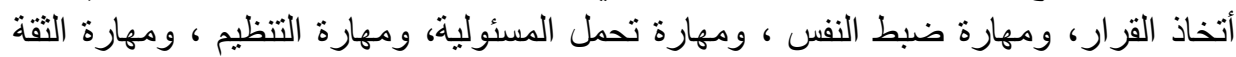
بالنفس ) لصالح الثباب المشارك حيث كانت جميع قيم(ت)دالة معنويا عند مستوى دلالة 0.001 ، كما تبين وجود فروق ذات دلالة إحصائية في قدرة الثباب على التخطيط للمستقبل

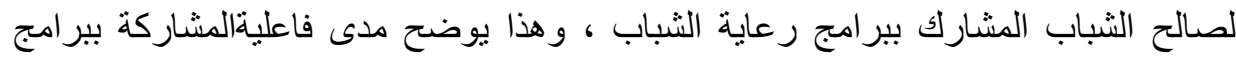
إدارةزعاية الثبابوالتى تعمل على تتمية القدرة على التخطيط للمستقبل واكساب المهارات المرتبطة بإدارة الذات ،ويتفق ذلك مع دراسة كل من ( Geraldk, 1999 ) ) ، منال عمار (

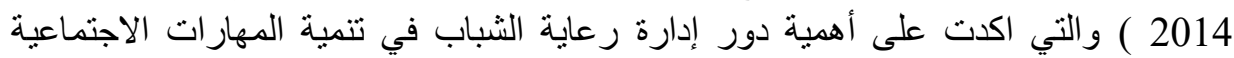
للطلاب و المشاركة في المجتمع وتثجيع التوجه الذاتي في الحياة ، بينما لم يتبين وجود فروق

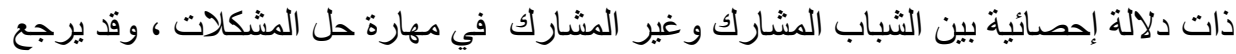

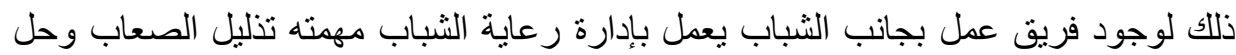
المشكلات التى قد يقابلها الثباب أثناء ممارسة انشطة البرامج وبذلك لا توجد الفرصة الثة الكافية لممارسة الشباب تللك المهارة، وبذلك تتحقق صحة الفرض الأول .

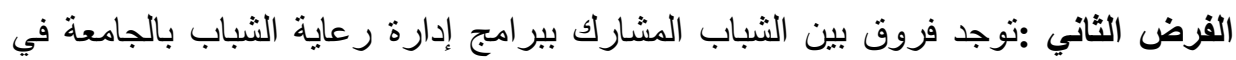
مهار ات إدارة الذات و القدرة على التخطيط للمستقبل وفقا لاختلاف النوع (ذكور ، اناث ). 
مجلة الاقتصاد المنزلى - مجلد 26 العدد الأول - 2016

جدول (9)الفروق بين ال شباب المشارك في برامج رعاية الثباب فيمهارات إدارة الذات

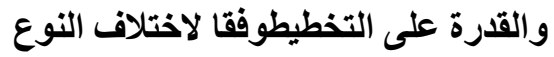

\begin{tabular}{|c|c|c|c|c|c|c|c|c|c|}
\hline \multirow{3}{*}{ الدلالة } & \multirow{3}{*}{ |قيمة (ت) } & \multicolumn{3}{|c|}{ إناث } & \multicolumn{3}{|c|}{ ذكور } & \multirow{3}{*}{\multicolumn{2}{|c|}{ المتغيرات }} \\
\hline & & |الخطأ | & |لانحراف| & |المتوسط & الخطأ & الانحراف & |المتوسط & & \\
\hline & & المعيارى | & |المعيارى | & الحسابي & المعيارى & المعيارى & |الحسابي | & & \\
\hline 0.001 & 4.4 & 0.55 & 3.9 & 32.7 & 0.45 & 2.7 & 35.8 & | اتخاذ القرار & مهارات \\
\hline 0.01 & 2.23 & 0.26 & 1.04 & 13.3 & 0.21 & 1.8 & 14.04 & ضبط النفس & \\
\hline غير دالة & 0.33 & 0.52 & 3.2 & 44.9 & 0.42 & 3.1 & 45.01 & السئولية & \\
\hline 0.01 & 2.25 & 0.39 & 1.9 & 61.7 & 0.32 & 2.5 & 62.8 & التظظيم & \\
\hline 0.01 & 2.2 & 0.39 & 2.4 & 22.1 & 0.31 & 2.3 & 23.2 & حل المشكلات & \\
\hline 0.001 & 4.4 & 0.29 & 2.01 & 21.8 & 0.24 & 1.6 & 23.5 & الثقة بالنفس & \\
\hline 0.001 & 3.3 & 1.9 & 10.7 & $\begin{array}{l}196.3 \\
\end{array}$ & 1.6 & 11.7 & 204.4 & |المهارات ككل & \\
\hline 0.001 & 3.02 & 0.41 & 2.5 & 45.6 & 034 & 2.4 & 47.2 & ط للمستقبل & التخطيط التط \\
\hline
\end{tabular}

تبين من خلالجدول (9) وجود فروق ذات دلالة إحصائية بين الثبابالمشارك ببرامج

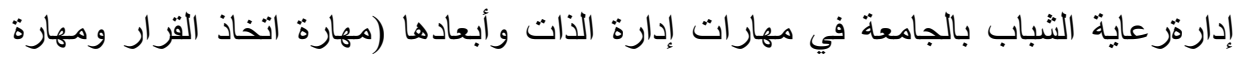

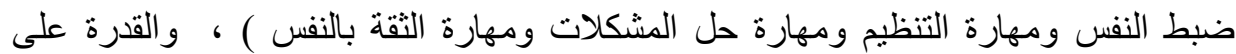

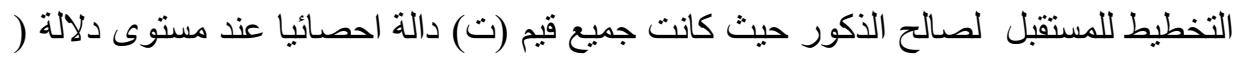

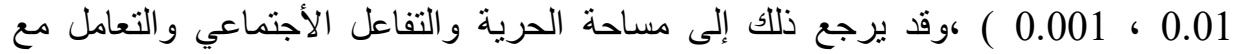
متغيرات الحياة والتى تعطى للأكور أكثر من الأناثوفقا لمحددات الثقافة المجتمعية والتنشئة

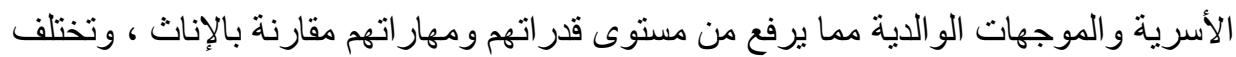

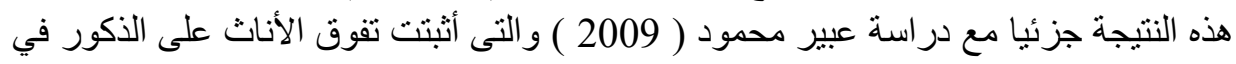

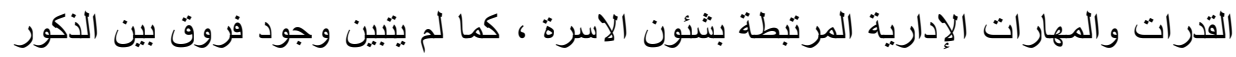

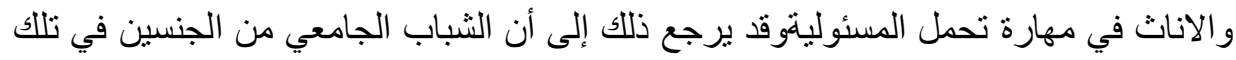

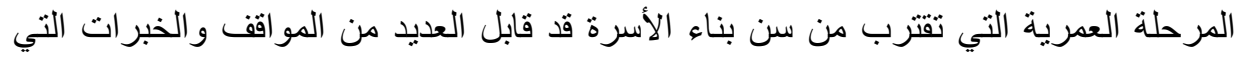

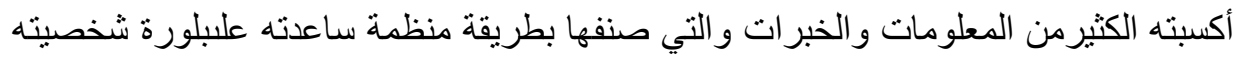

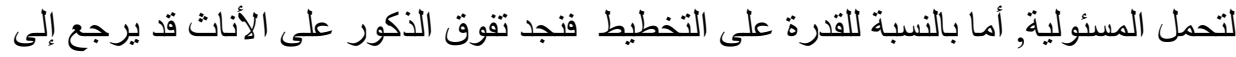

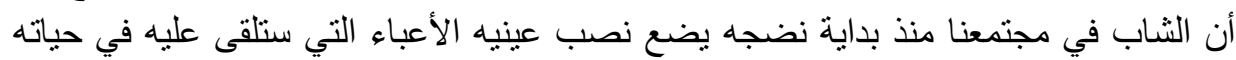

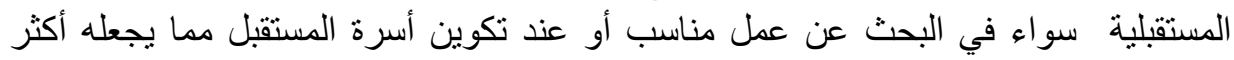

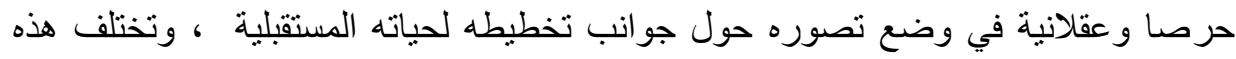

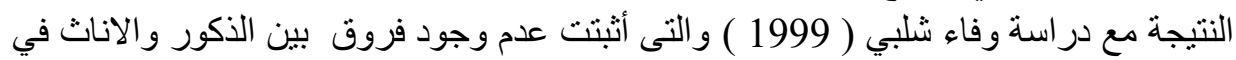

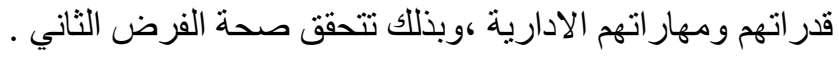


مجلة الاقتصاد المنزلى - مجلد 26 العدد الأول - 2016

الفرض الثالث :توجد فروق ذات دلالة إحصائية في مهارات ادارة الذات للثباب

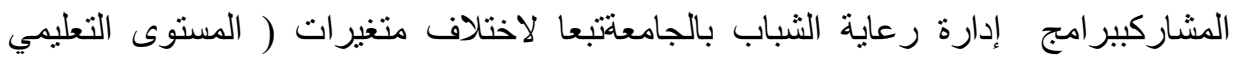

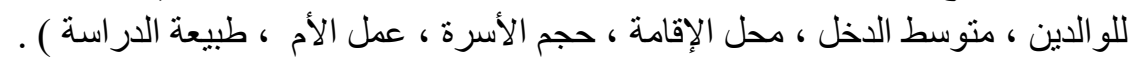

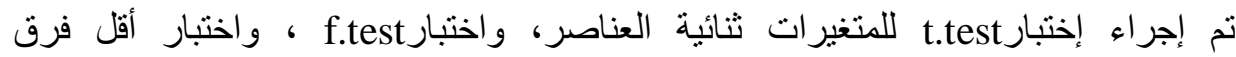

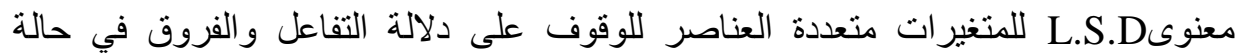

جدول (10)الفروق في مهارات إدارة الذات تبعاً لمتغيرات محل الإقامة

وجودها.

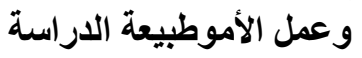

\begin{tabular}{|c|c|c|c|c|c|c|}
\hline الالالة & 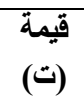 & المعيارى الخطأ & الالمعرافي & المتوسط الحسابي & \multicolumn{2}{|c|}{ المتغيرات } \\
\hline \multirow{2}{*}{ غيردالة } & \multirow{2}{*}{0.95} & 1.9 & 13.8 & 202.6 & حضر & \multirow{2}{*}{ الإقامة } \\
\hline & & 1.7 & 10.2 & 200.1 & ريف & \\
\hline \multirow{2}{*}{0.001} & \multirow{2}{*}{3.9} & 1.6 & 13.2 & 205.3 & عاملة & \multirow{2}{*}{ عمل الأم } \\
\hline & & 1.8 & 7.5 & 195.9 & غير عاملة & \\
\hline \multirow{2}{*}{0.001} & \multirow{2}{*}{11.9} & 1.3 & 2.4 & 189.1 & نظرية & \multirow{2}{*}{ الاربيعة } \\
\hline & & 0.9 & 9.2 & 208.5 & عملية & \\
\hline
\end{tabular}

أوضح جدول (10) عدم وجود فروق ذات دلالة إحصائية في مهارات إدارة الذات

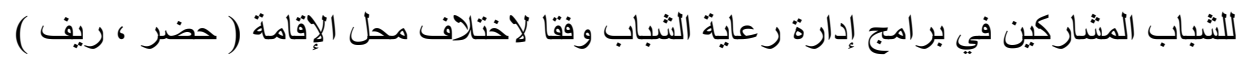

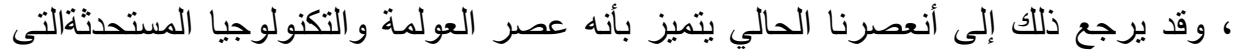

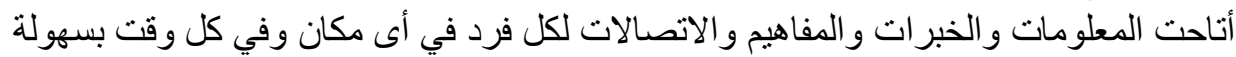

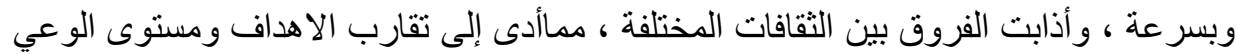

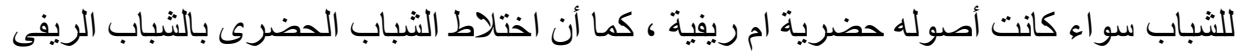

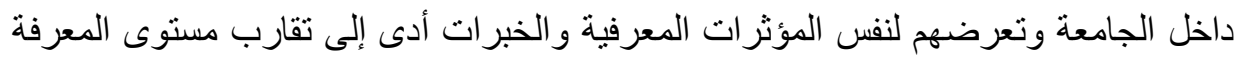

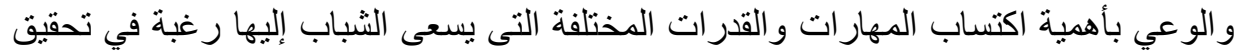

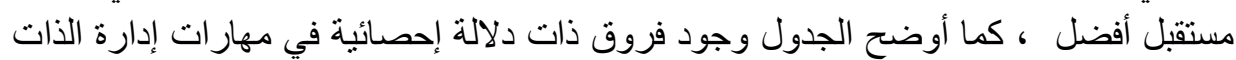

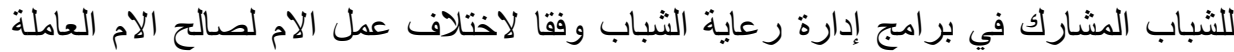

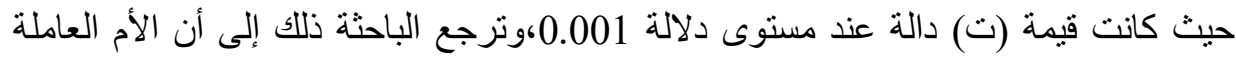

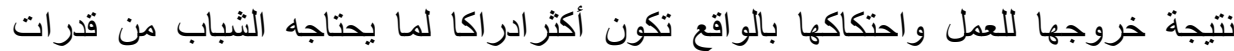

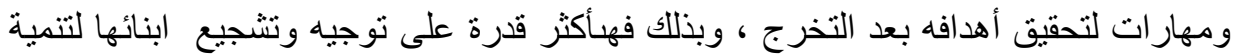

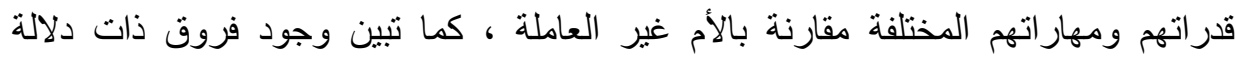

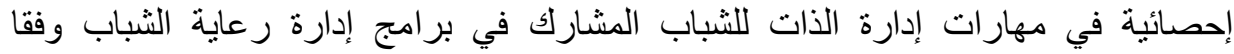

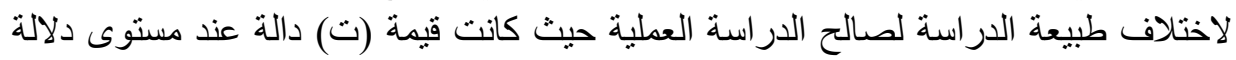

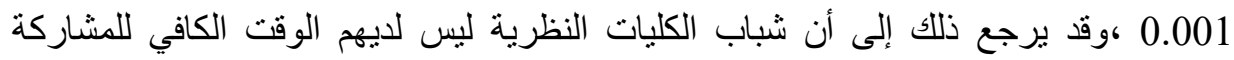

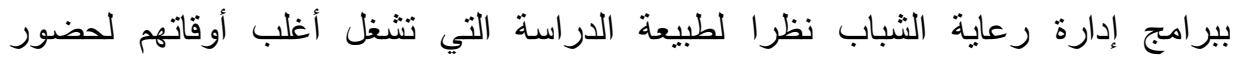




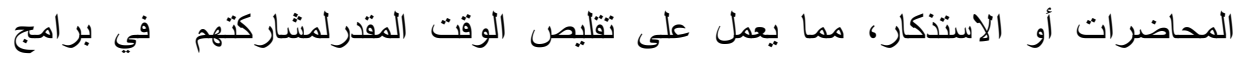

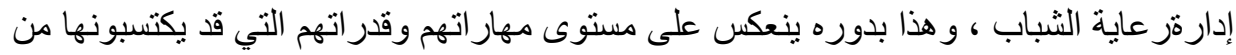

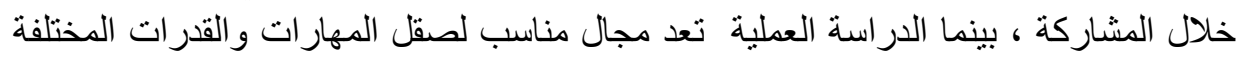

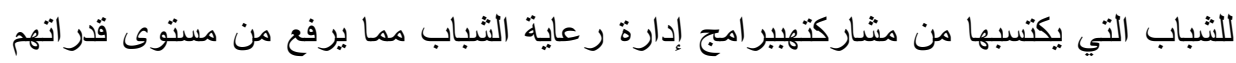

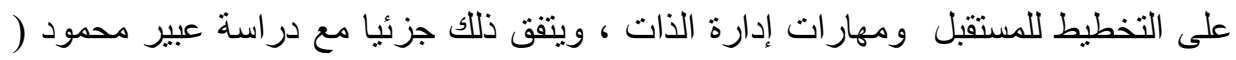

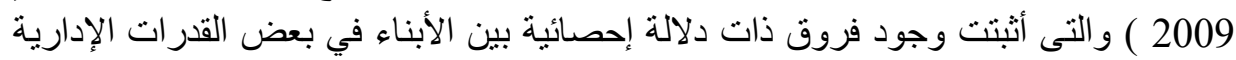

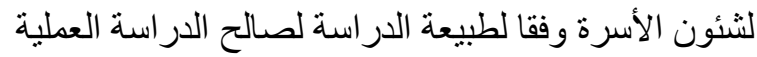

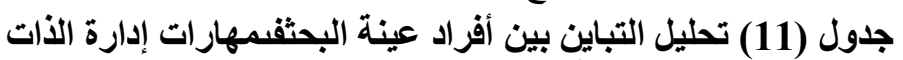
تبعاً لبعض متغيرات البحث البه

\begin{tabular}{|c|c|c|c|c|c|c|}
\hline مستوى الدلاية & قيمة (ف) & المربعات & المربعات & الحرية & مصدر التباين & المتغيرات \\
\hline 0.001 & 9.9 & $\begin{array}{c}1174.2 \\
119.2\end{array}$ & $\begin{array}{l}2348.48 \\
1012.41 \\
12476.8\end{array}$ & $\begin{array}{c}2 \\
85 \\
87\end{array}$ & باخل المجموعات التباين الكلي & الام مستوى تعليم \\
\hline 0.001 & 24.8 & $\begin{array}{c}2790.1 \\
112.6\end{array}$ & $\begin{array}{c}2790.1 \\
9686.8 \\
12476.9\end{array}$ & \begin{tabular}{c|}
1 \\
86 \\
87
\end{tabular} & داخل المجموعات المبات المبن & الأبتوى تعليم \\
\hline 0.001 & 5.8 & $\begin{array}{l}758.0 \\
128.9\end{array}$ & $\begin{array}{c}1516.1 \\
10960.8 \\
12476.9\end{array}$ & $\begin{array}{c}2 \\
85 \\
87 \\
\end{array}$ & باخل المجموعات التباتين الكلي & متوسط الاخل \\
\hline 0.001 & 34.1 & $\begin{array}{c}2778.1 \\
81.4\end{array}$ & $\begin{array}{c}5556.3 \\
6920.6 \\
12476.9\end{array}$ & $\begin{array}{c}2 \\
85 \\
87\end{array}$ & داخل المجموعات المبات & حجم الأسرة \\
\hline
\end{tabular}

تبين من جدول (11) وجود فروق ذات فات دلالة إحصائية في مهارات إدارة الذات

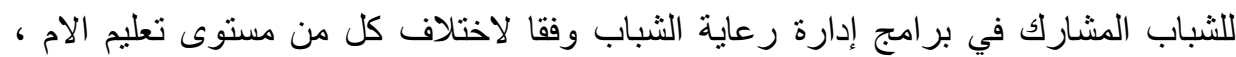

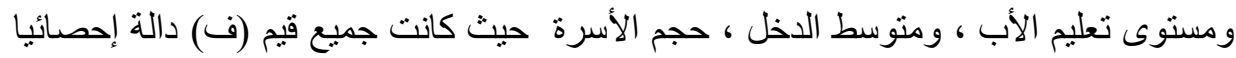

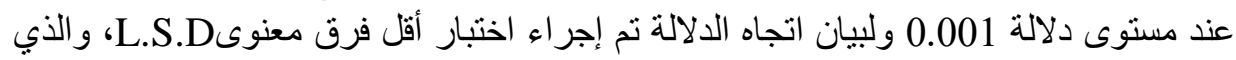

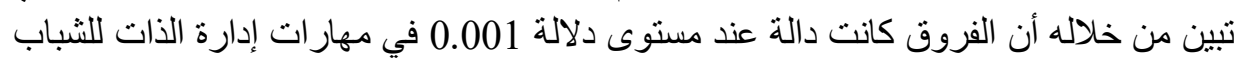

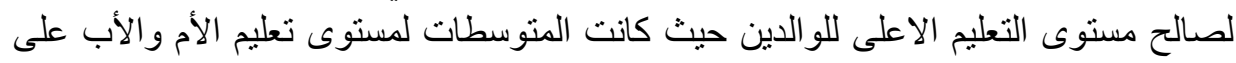

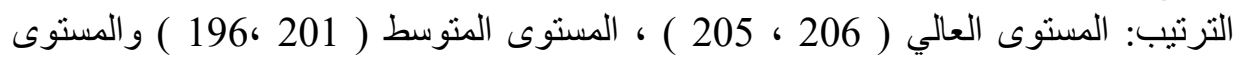

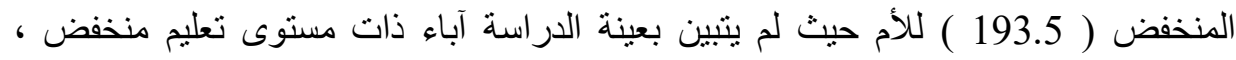

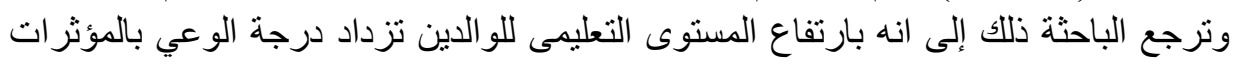

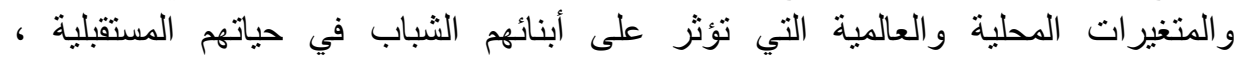

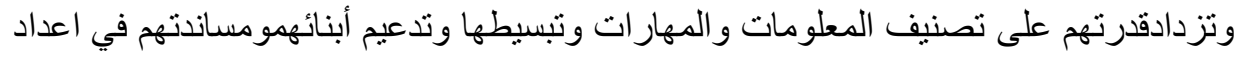

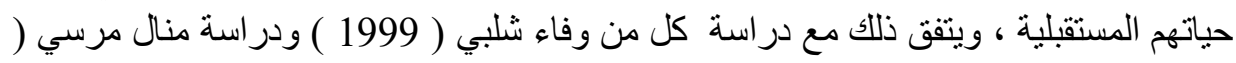

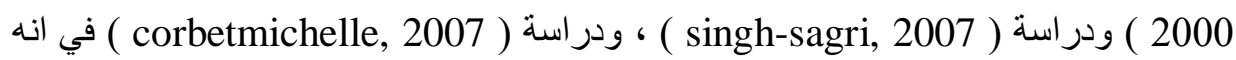


بارتفاع المستوى التعليمي للوالدين تزداد القدرة على اكساب الأبناء المعلومات والمهارات

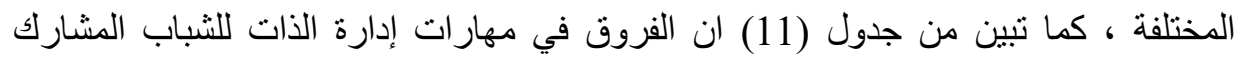

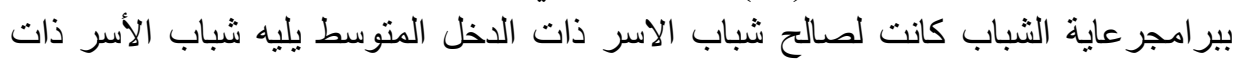

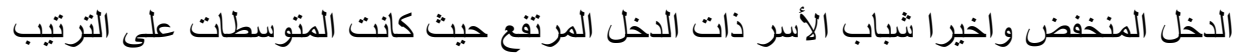

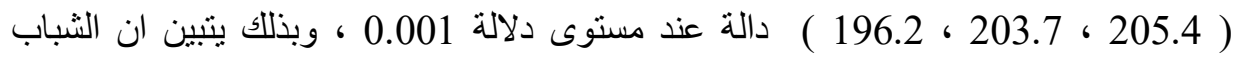

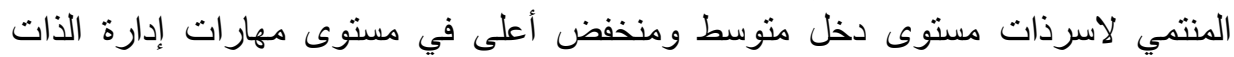

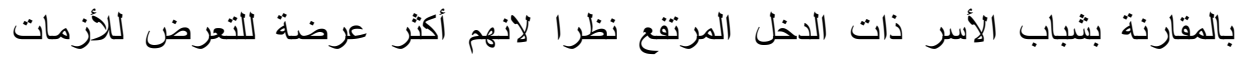

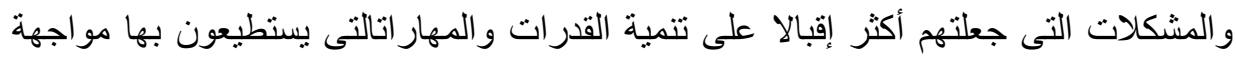

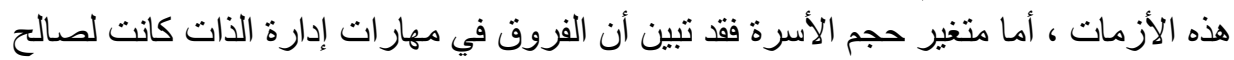

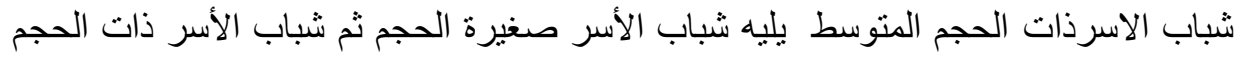

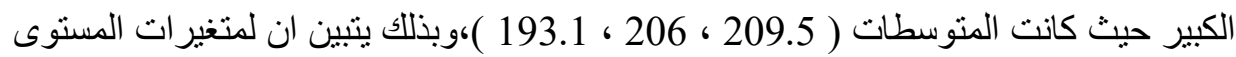

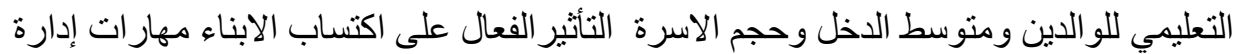

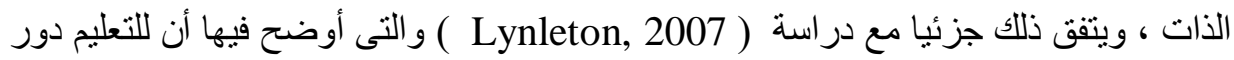

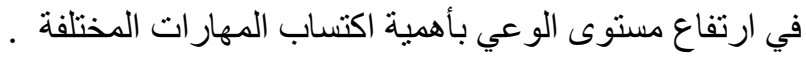

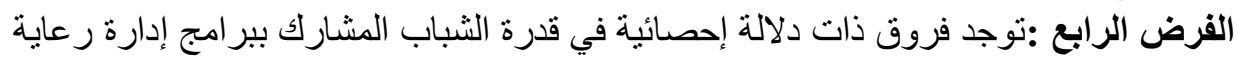

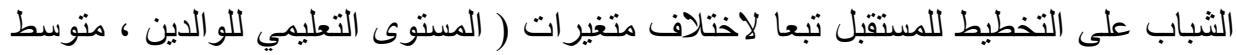

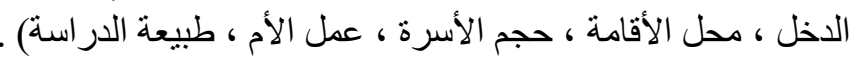

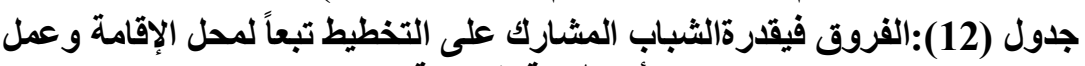
الأموطبيعة الاراسة الاسية

\begin{tabular}{|c|c|c|c|c|c|c|}
\hline الدلالة & قيمة (ت) & الخطأ المعيارى & الانحراف المعياري & المتوسط الحسابي & ج & \\
\hline \multirow[t]{2}{*}{ غيردالة } & \multirow[t]{2}{*}{2.2} & 0.39 & 2.3 & 47.3 & حضر & \multirow{2}{*}{ الإقامة } \\
\hline & & 0.36 & 2.7 & 46.1 & ريف & \\
\hline \multirow[t]{2}{*}{0.001} & \multirow[t]{2}{*}{6.5} & 0.29 & 2.2 & 47.9 & عاملة & عمل \\
\hline & & 0.34 & 1.9 & 44.9 & غير عاملة & الأم \\
\hline \multirow[t]{2}{*}{0.001} & \multirow[t]{2}{*}{10.1} & 0.30 & 1.6 & 44.2 & نظريةة & طبيعة \\
\hline & & 0.24 & 1.8 & 48.1 & عملية & الدراسة \\
\hline
\end{tabular}

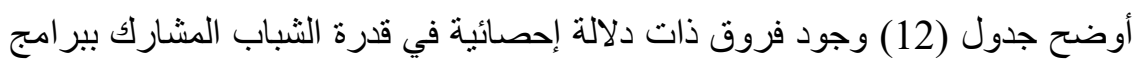

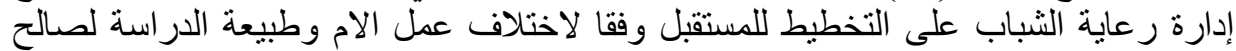

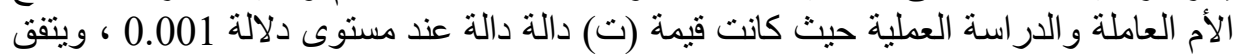

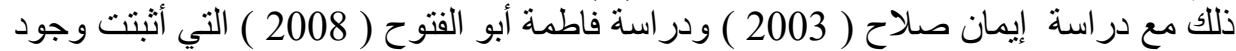

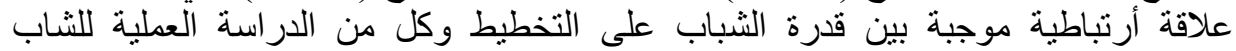

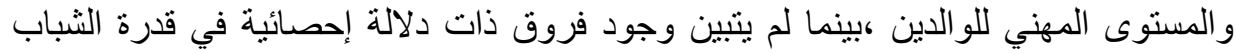

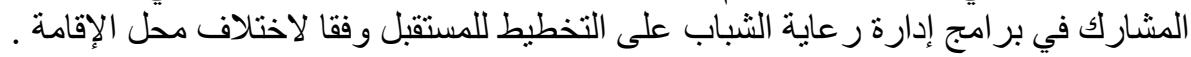


مجلة الاقتصاد المنزلى - مجلد 26 العدد الأول - 2016

جدول (13) تحليل التباين بين أفراد عينة البحثفـالقدرة على التخطيط للمستقبل

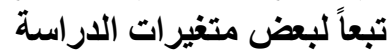

\begin{tabular}{|c|c|c|c|c|c|c|}
\hline مستوّي & قيمة ( ف) & المربعات & المربعوات & الدرجية & مصدرالتباين & المتغيرات \\
\hline 0.001 & 28.2 & $\begin{array}{c}114.3 \\
4.1\end{array}$ & $\begin{array}{c}228.6 \\
344.5 \\
573.08\end{array}$ & $\begin{array}{c}2 \\
85 \\
87\end{array}$ & دأخلّ المجموعات التباتين & تعليم الام \\
\hline 0.001 & 54.1 & $\begin{array}{c}221.4 \\
4.1\end{array}$ & $\begin{array}{l}221.4 \\
351.7 \\
573.1\end{array}$ & $\begin{array}{c}1 \\
86 \\
87\end{array}$ & داخلّ المجموعات التبات & تعليم الأب \\
\hline غيردالة & 2.6 & $\begin{array}{c}16.5 \\
6.4\end{array}$ & $\begin{array}{r}33.1 \\
539.9 \\
573.1\end{array}$ & $\begin{array}{c}2 \\
85 \\
87\end{array}$ & دأخلِ المجموعات الكبات & متوسط \\
\hline 0.001 & 34.1 & $\begin{array}{c}2778.1 \\
81.4\end{array}$ & $\begin{array}{r}5556.3 \\
6920.6 \\
12476.9\end{array}$ & $\begin{array}{c}2 \\
85 \\
87\end{array}$ & داخلّل المجموعات المباتِ & حجم الأسرة \\
\hline
\end{tabular}

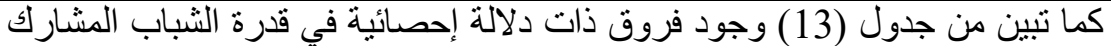

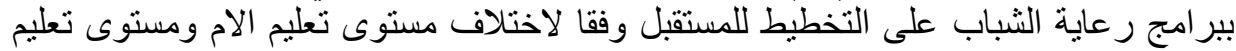

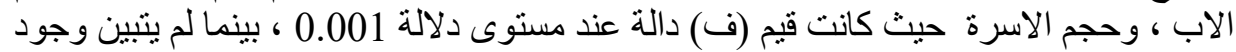

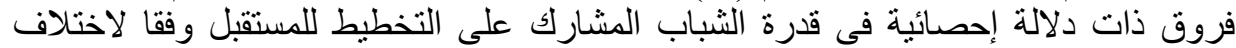

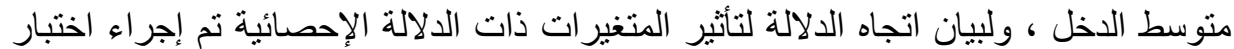

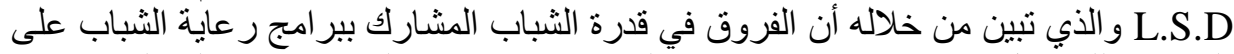

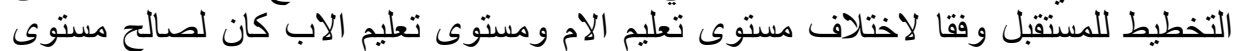

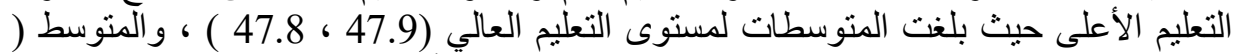

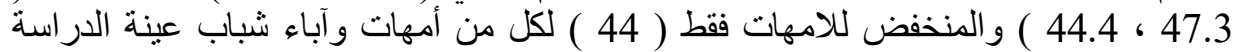

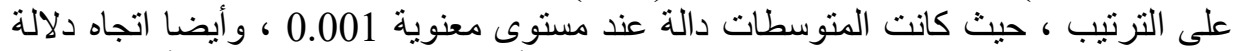

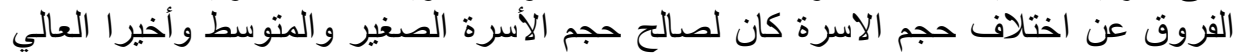

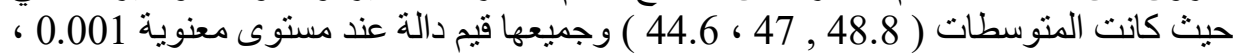

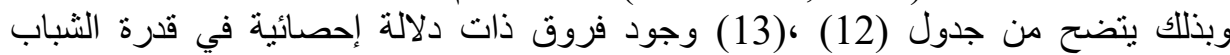

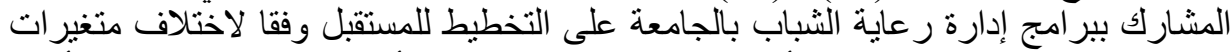

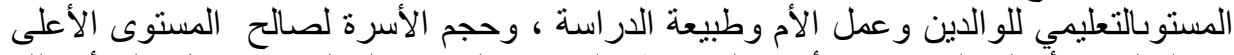

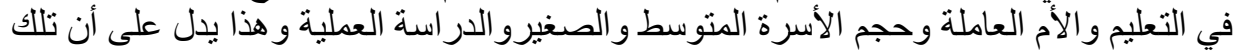

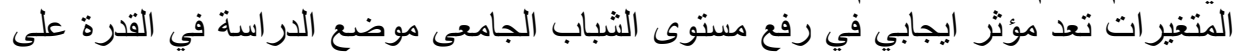

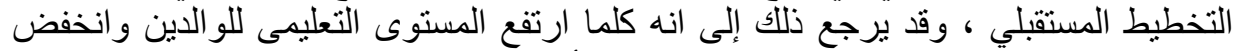

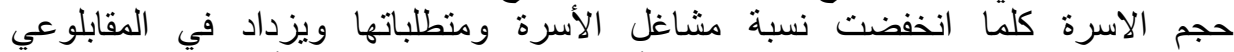

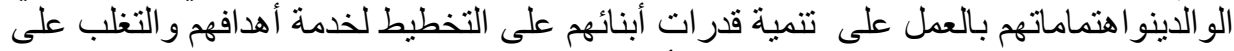

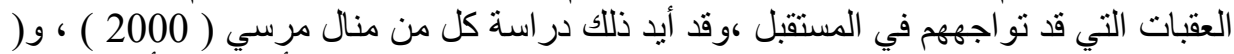

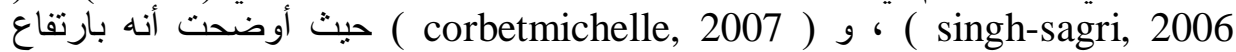

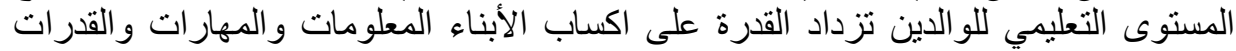

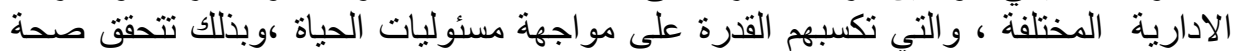

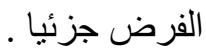


مجلة الاقتصاد المنزلى - مجلد 26 العدد الأول - 2016

الفرض الخامس : توجد علاقة ارتباطية ذات دلالة إحصائية بين مشاركة الثباب بير امج إدارة

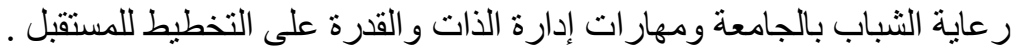

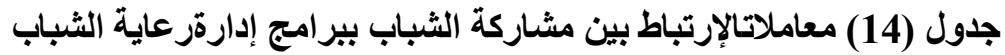

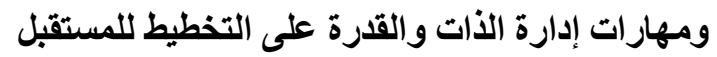

\begin{tabular}{|c|c|c|c|c|c|c|c|c|}
\hline اللقستقبط & | الذات كهارة & بالنفس & مهارة حلات & إلدارة & لمهارؤ تحملة & ضهبط & القرارات & \\
\hline 0.87 & 0.72 & 0.89 & 0.75 & 0.77 & 0.54 & 0.43 & 0.63 & بيرامج رعاركة الشباب الثبب \\
\hline 0.001 & 0.001 & 0.001 & 0.001 & 0.001 & 0.001 & 0.001 & 0.001 & (مستوى الالالة ) \\
\hline
\end{tabular}

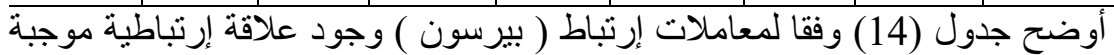

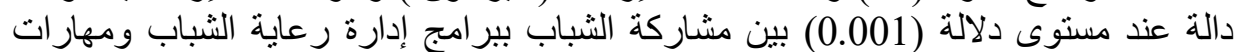

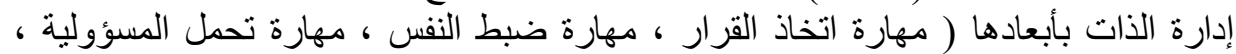

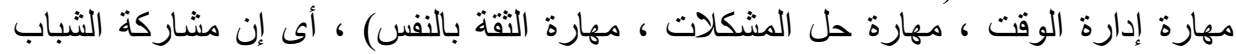

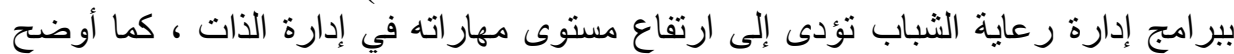

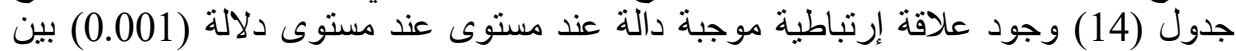

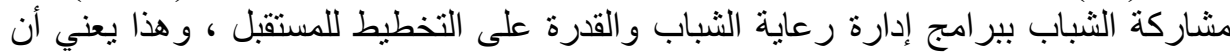

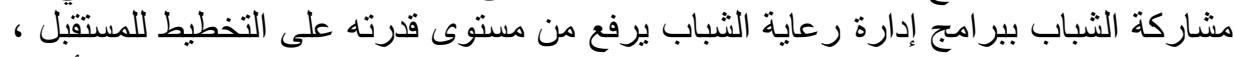

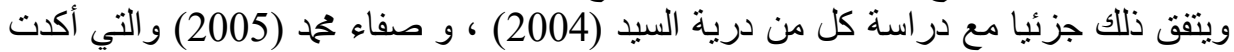
على أهمية ممارسة الأنشطة الطلابية في النمو المتكامل لثخصية الطلاب ، و التوجها الذاتي في في

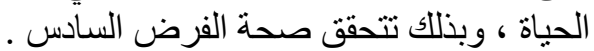

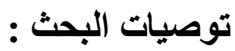

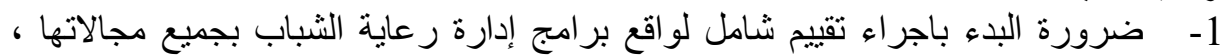

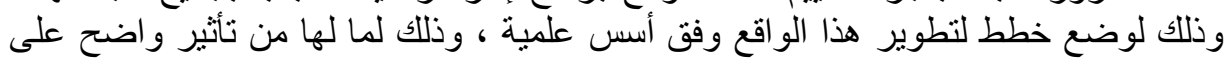

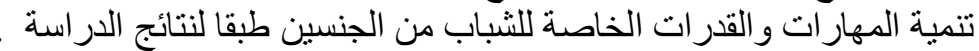

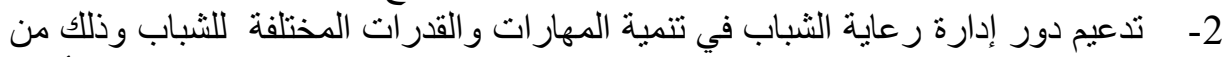

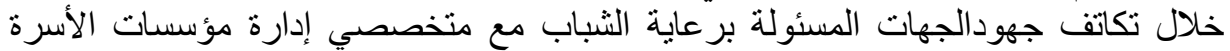

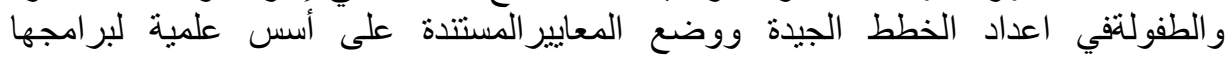
وخدماتهالاكساب الثباب المهارات المختلفة والقدرة على التخطيط للحياة المستقبلية وكيفية

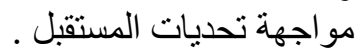

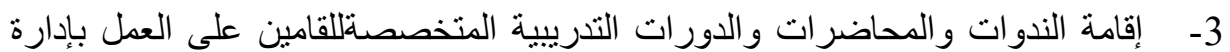

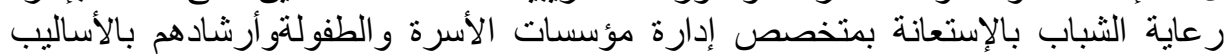

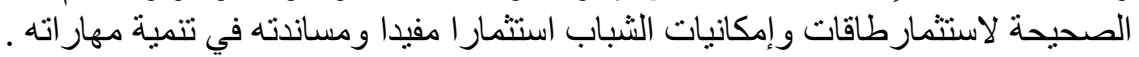

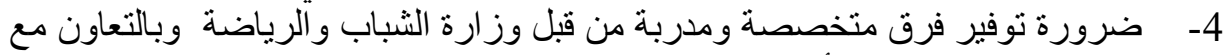

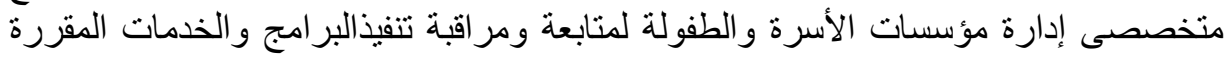
لإدارة رعاية الثباب بالجامعات ومعالجة القصور ونقاط الضعة الضعف بالإدارة حتى ينال الثباب

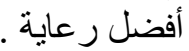


1- ابراهيم رمضان الديب ( 2009 ) ) : أسس ومهارات إدارة الذات وصناعة التغيير

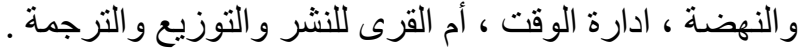

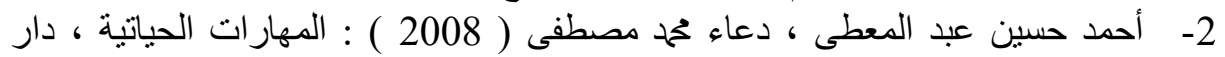

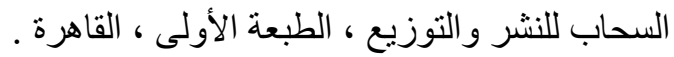
3- الإدارةالمركزى للتعبئة العامة والإلعة الإلى ، اللصاء( 2013 ) : الكتاب الإحصائي السنوى 2012/1/1

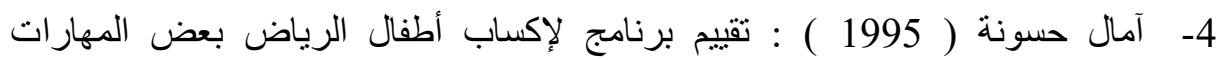

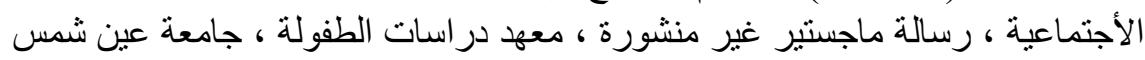

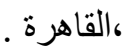

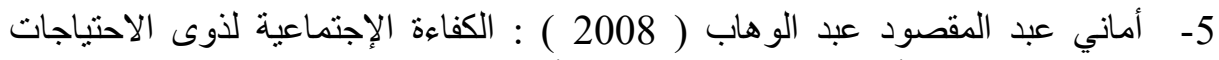

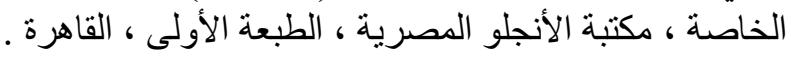

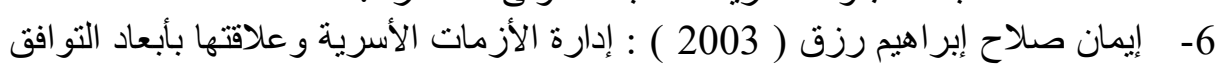

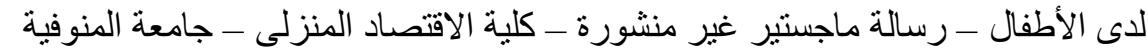

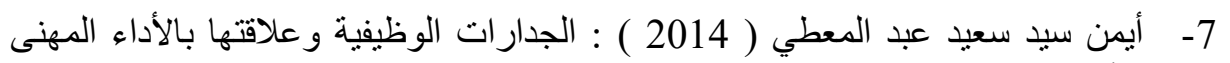

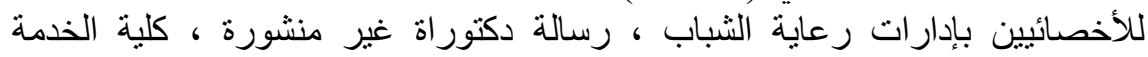
الإجتماعية ، جامعة الفيوم . الإن

8- إيهاب صبيح ( 2000 ) : الإدارة - الأصول والنظريات ـ دار الكتب العلمية للنشر والتوزيع.

9- بثنينة عمارة ( 2002 ) : العولمة وتحديات العصر و انعكاساتها على المجتمع المصري ، دار الأمين ، القاهرة (2002 .

10- بشير صالح الرشيدي ( 2000 ) ) : مناهج البحث التربوى ، رؤية تطبيقية مبسطة ، دار

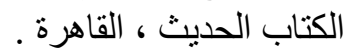
11- تومادر مصطفى أحمد ( 2001 ) : المهار ات المهنية للأخصائي الإجتماعي المنظم في

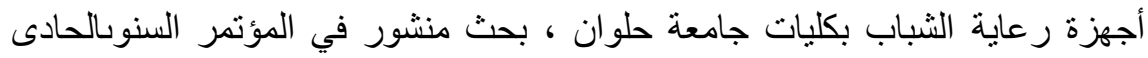

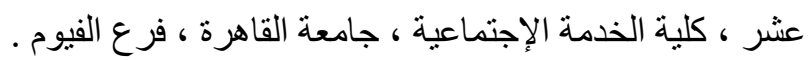

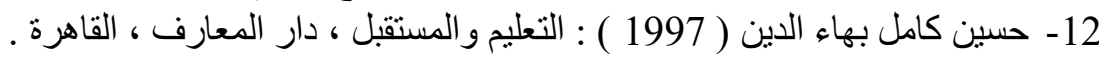

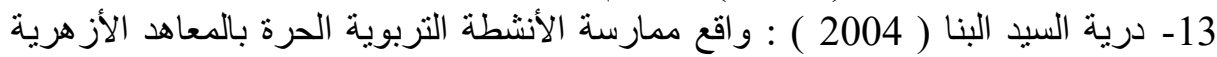

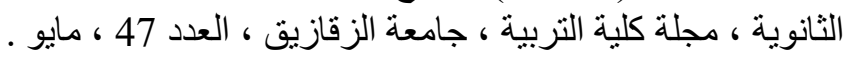

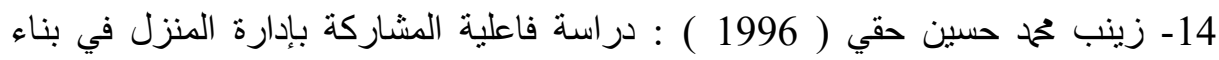

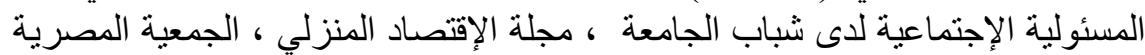

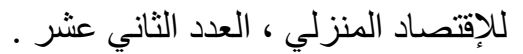

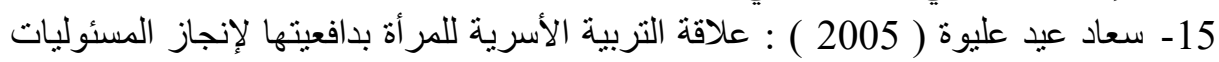

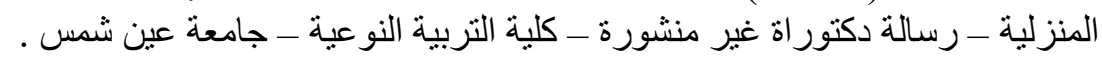


مجلة الاقتصاد المنزلى - مجلد 26 العدد الأول - 2016

16- سميرة إبراهيم حسن ( 2008 ) : : تقويم جهود المنظمات غير الحكومية في محو أمية

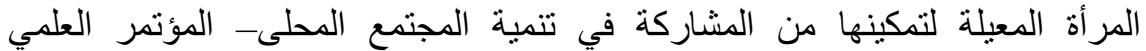

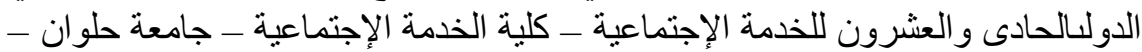

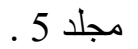
17- صفاء محم على أحمد ( 2005 ) : الأنشطة الطلابية ودور ها في تنمية الوعي السياسي

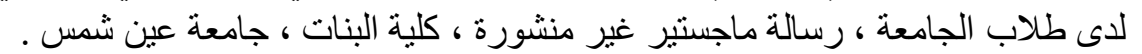

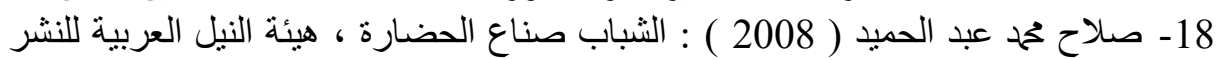

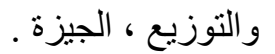
19- عبد الرحمن ححمد العيسوى ( 1996 ) : : علم النفس في المجال التربوي ، دار المعرفة

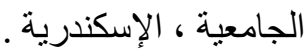

20- عبد المحيي محمود حسن ( 2000 ) ) : الخدمة الأجتماعية ومجالات الممارسة المهنية ، دار المعرفة الجامعية ، الإسكندرية .

21- عبير محمود الدويك ( 2009 ) : دور الأبناء في إدارة شئون الأسرة وعلاقته بالتو افق الأق

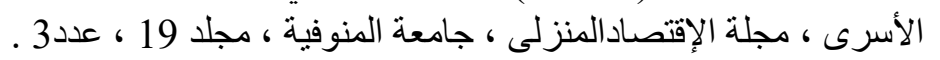

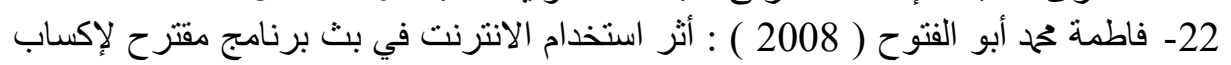

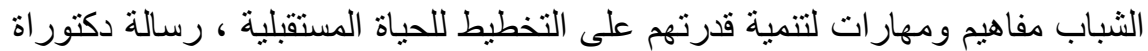

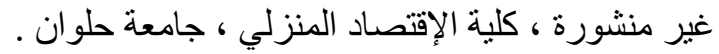

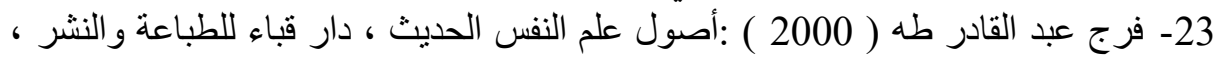

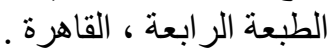
24- ماهر أبو المعاطي على ( 2003 الرة ) ) : الخدمة الإجتماعية في مجال رعاية الثباب ، مكتبة

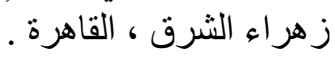

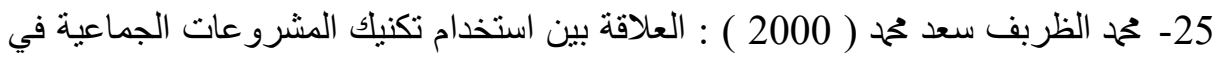

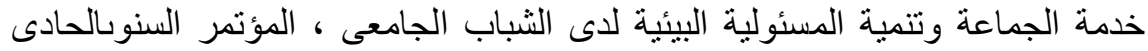

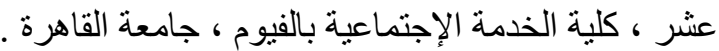

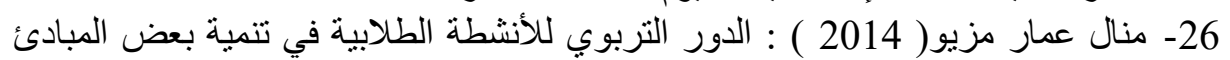

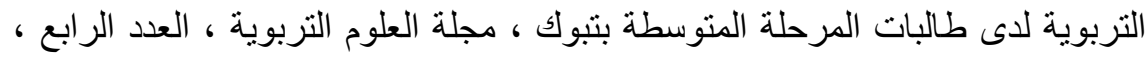
27- منال مرسي الثنامي ( 2000 ) : الممارسات الإدارية للمر اهقة وأثر ها على تصور ها الإلها

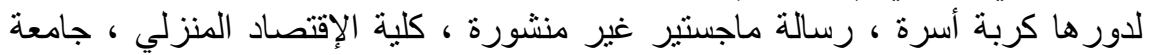

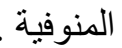

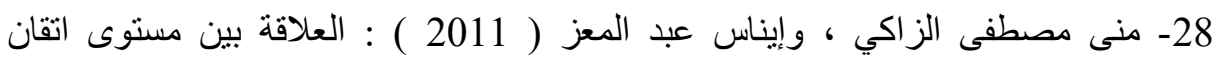

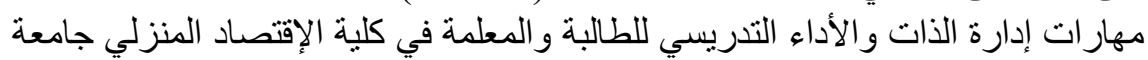
الازهر، المؤتمر العربي السادس ، الدولى الثالث ، كلية التربية النوعية ، جامعة الإلية 


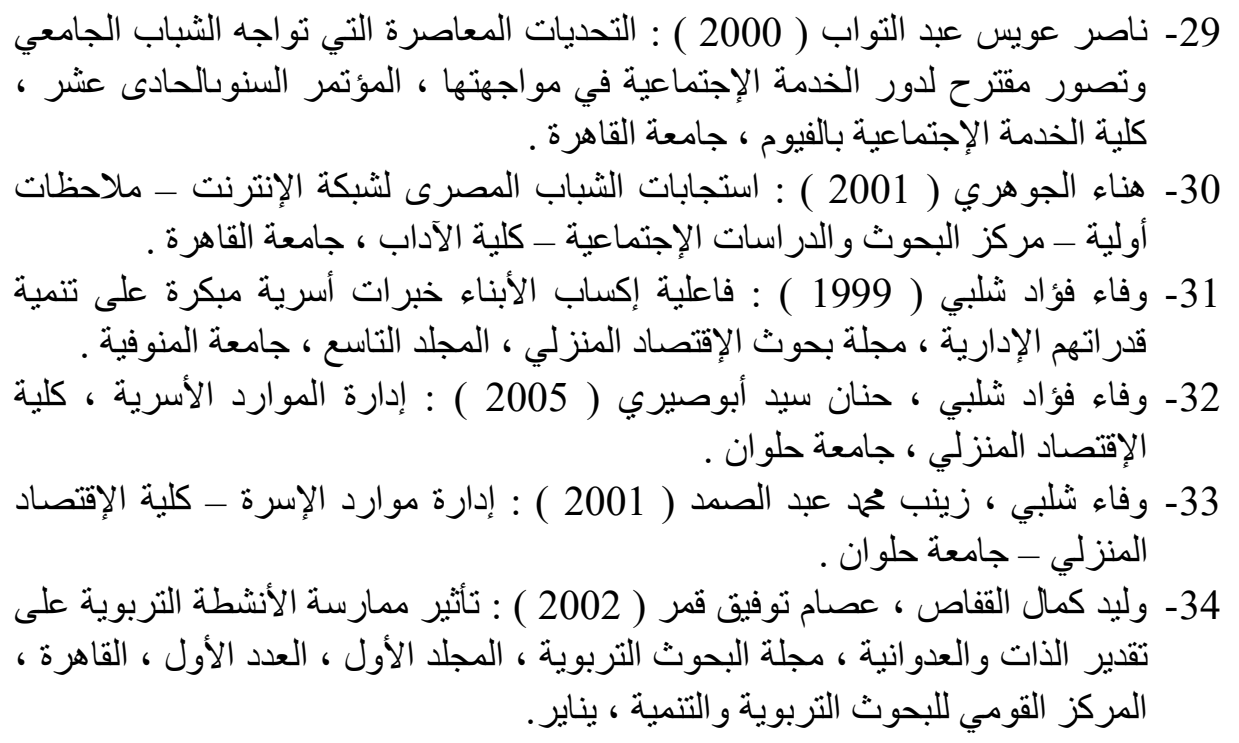

35- Corbett A. Michelle, ( 2007 ) : Factors affecting choice of contraceptive method among young women-southern, Connecticut state university .

36- Demaine Jack ( 2001 ) : Sociology of education today, PalgrvePublishLTD,England.

37-Durham Wesley T. ( 2004 ) : The family planning communicational of voluntarily child-free. Couples, dissertation abstracts international vol.65, No.1

38-Geraldk, letendre( 1999 ) : Community- building activities inJapanese school, alternative parading of the democratic school, comparative education review, vol. 43 , Na 3, August.

39-Lyn Leton, ( 2007 ) : Strengthening social skills for life long learning, Pennsylvania.

40- Singh-Sagri, (2006 ) : Premarital family role, family planning information in fertility and contraceptive use among rural women in India- The johns Hopkins university. 
مجلة الاقتصاد المنزلى - مجلد 26 العدد الأول - 2016

\title{
The participation in the programs of the youth- care administration at the university andits relationship with the self- management skills and the capability for the future planning
}

\author{
HananSamy Mohammed Mohamed Abdel-Atti
}

Assistant Professor, Department of the Management of the Family and Childhood Establishments, Faculty of Home Economics- Helwan University

\begin{abstract}
:
This research aims to study the participation of the youth in the programs of the youth- care administration at the universityand its relationship with the self- management skills and the capability for the future planning. The study sample consisted of 204 male and female college students from Cairo and Helwan Universities "17-23years old", 88 of 204 students engaged in the activities of these programs, and 116 students did not participate in these programs, all of them were of disparate socioeconomic levels. The study tools included the primary data form for the youth, the questionnaire for the participation in the programs of the youth- care administration, the self-management skills scale, and the capability for the future planning scale. The results revealed that, there was a positive association between the participation in the programs of the youth- careadministration, the self- management skills and the capability for the future planning, as the association was significant at level 0.001 . The highest percentage of the youth involved in the youth- care programs lied in the category of moderate and high levels of the self- management skills, $46.6 \%, 44.3 \%$ respectively, while the highest percentage of the youth non-involved in the youth- care programs lied in the category of low and moderate, $44.8 \%, 39.7 \%$ respectively. The highest percentage of the youth involved in the youthcare programs lied in the category of high levels ofthe capability for the future planning, $69.4 \%$, respectively, while the highest percentage of the youth non-involved in the youth- care programs lied in the category of moderate $47.4 \%$ respectively. There were also statistically significant differences concerning the self- management skills and the capability for the future planning in the youth involved and non-involved in the youthcare programs for the youth participants at significance level 0.001. There were also statistically significant differences among the youth involved in the youth- care programs in terms of the self- management skills according to (the gender- nature of the study- parents' educational
\end{abstract}




\section{مجلة الاقتصاد المنزلى - مجلد 26 العدد الأول - 2016}

level- family size- family's average income- mother's work- residency) for the male youth, practical study, parents' higher educational level, family's small and medium size, family's low and moderate income, and the working mother at significance level 0.001. But, there were no statistically significant differences regarding the self- management skills according to the residency (urban- rural areas). There were also statistically significant differences in terms of the capability for the future planning according to (the gender- nature of the study- parents' educational level- family size- family's average income- mother's workresidency) for the male youth, practical study, parents' higher educational level, family's small and medium size, and the working mother at significance level 0.001 . However, there were no statistically significant differences in terms of the capability for the future planning according to the difference in the residency and the average income. 